\title{
Purification, Purity, and Freezing Points of 8 Nonanes, 11 Alkylcyclopentanes, 6 Alkylcyclohexanes, and 4 Butylbenzenes of the API-Standard and API-NBS Series*
}

\author{
By Anton J. Streiff, ${ }^{2}$ Evelyn T. Murphy, ${ }^{2}$ Janice C. Cahill, ${ }^{2}$ Helen F. Flanagan, ${ }^{2}$ \\ Vincent A. Sedlak, ${ }^{2}$ Charles B. Willingham, and Frederick D. Rossini
}

This report describes the purification and determination of freezing points and purity of 29 hydrocarbons of the API-Standard and API-NBS series, including 8 nonanes, 11 alkylcyclopentanes, 6 alkylcyclohexanes, and 4 butylbenzenes.

\section{Introduction}

A previous report described the purification, and determination of freezing points and purity of 37 hydrocarbon compounds of the APIStandard and API-NBS series, which were produced as part of the cooperative program on standard samples of hydrocarbons of the National Bureau of Standards and the American Petroleum Institute. This report describes the purification and determination of freezing points and purity of an additional 29 hydrocarbon compounds under this cooperative program, including 8 nonanes, 6 alkylcyclohexanes, 11 alkylcyclopentanes, and 4 butylbenzenes. ${ }^{3}$

The final lots of the material labeled APIStandard are sealed "in vacuum" in glass ampoules and made available as NBS standard samples of

*Presented before the Division of Petroleum Chemistry of the American Chemical Society, Chicago, Ill., September 1946.

**Figures in brackets indicate the literature references at the end of this paper.

1 This investigation was performed at the National Bureau of Standards as part of the work of the American Petroleum Institute Research Project 6 on the Analysis, Purification, and Properties of Hydrocarbons.

${ }^{2}$ Research Associate on the American Petroleum Institute Research Project 6 at the National Bureau of Standards.

3 The cooperative program was carried on under the API Research Project 46 Committee on Hydrocarbons for Spectrometer Calibration (W. J. Sweeney, chairman). Further details are given in references [1, 2, 3]. hydrocarbons [4].** The material labeled APINBS is made available in appropriate small lots on loan to qualified investigators for the measurement of needed properties. ${ }^{4}$

\section{Materials}

The starting materials were supplied as follows: ${ }^{5}$

By the API Research Project 45 on the "Synthesis and Properties of Hydrocarbons of Low Molecular Weight" at the Ohio State University, Columbus, Ohio, under the supervision of C. E. Boord:

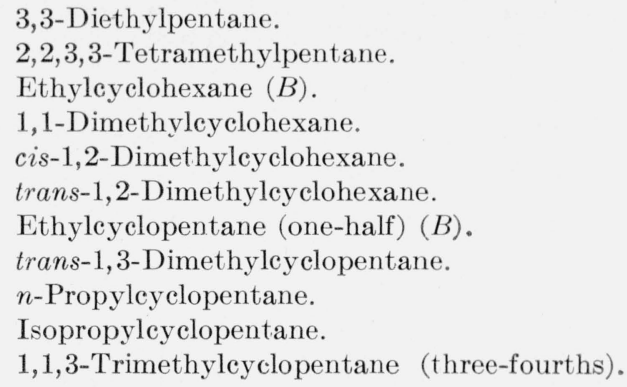

${ }_{4}$ The allocation of the API-NBS samples of hydrocarbons is handled by the Advisory Committee for the API Research Project 44 on the "Collection, Analysis, and Calculation of Data on the Properties of Hydrocarbons" (W. E. Kuhn, chairman).

${ }^{5}(B)$ following the name of a compound indicates that, for the API-NBS series, it is a second (and usually slightly purer) sample of the given compound, the first sample of which is labeled $(A)$. (See reference [5]). 
By the Hydrocarbon Laboratory at the Pennsylvania State College, State College, Pa., under the supervision of F. C. Whitmore:

2,4,4-Trimethylhexane.

Ethylcyclopentane (one-half) $(B)$.

1,1-Dimethylcyclopentane.

cis-1,2-Dimethylcyclopentane.

trans-1,2-Dimethylcyclopentane.

1,1,2-Trimethylcyclopentane.

cis, cis, trans-1,2,4-Trimethylcyclopentane.

cis, trans, cis-1,2,4-Trimethylcyclopentane.

By the National Advisory Committee for Aeronautics, through its Aeronautical Engine Research Laboratory at Cleveland, Ohio, and the Automotive Section at the National Bureau of Standards :

\begin{tabular}{|c|c|c|}
\hline $\begin{array}{l}n \text {-Butylbenzene } \\
\text { Isobutylbenzene } \\
\text { sec-Butylbenzene } \\
\text { tert-Butylbenzene }\end{array}$ & $\begin{array}{l}(B) . \\
(B) . \\
(B) . \\
(B) .\end{array}$ & $\begin{array}{l}2,2,3,4 \text {-Tetramethylpen- } \\
\text { tane. } \\
2,2,4,4 \text {-Tetramethylpen- } \\
\text { tane. } \\
2,3,3,4 \text {-Tetramethylpen- } \\
\text { tane }\end{array}$ \\
\hline
\end{tabular}

By the Standard Oil Development Co., Elizabeth, N. J., through W. J. Sweeney:

cis-1,4-Dimethylcyclohexane. trans-1,4-Dimethylcyclohexane.

By the Gulf Oil Co. Fellowship at the Mellon Institute of Industrial Research, Pittsburgh, Pa., through W. A. Gruse:

\section{1,1,3-Trimethylcyclopentane (one-fourth).}

By the API Research Project 6 at the National Bureau of Standards, under the supervision of F. D. Rossini :

$$
\text { n-Nonane. 2,2,5-Trimethylhexane. }
$$

Table 1 summarizes the amounts of the starting materials and gives some additional information as to the source and purity.

TABLE 1.-Information on the purification of 29 API-Standard and API-NBS hydrocarbons

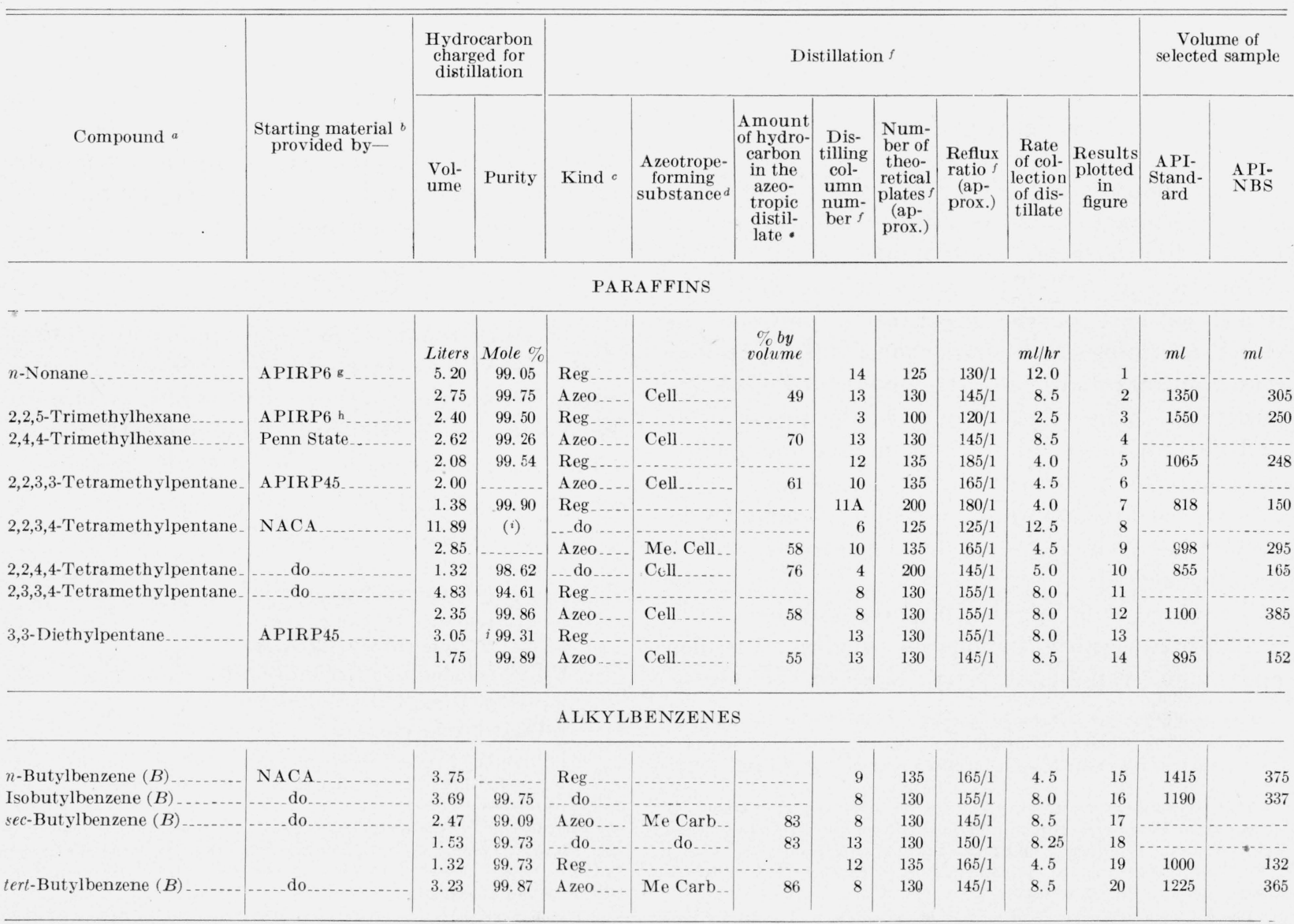

Footnotes on page 56 . 
TABLE 1.-Information on the purification of 29 API-Standard and API-NBS hydrocarbons-Continued

\begin{tabular}{|c|c|c|c|c|c|c|c|c|c|c|c|c|c|}
\hline \multirow[b]{2}{*}{ Compound $a$} & \multirow[b]{2}{*}{$\begin{array}{l}\text { Starting material } \\
\text { provided by- }\end{array}$} & \multicolumn{2}{|c|}{$\begin{array}{l}\text { Hydrocarbon } \\
\text { charged for } \\
\text { distillation }\end{array}$} & \multicolumn{8}{|c|}{ Distillation ${ }^{f}$} & \multicolumn{2}{|c|}{$\begin{array}{c}\text { Volume of } \\
\text { selected sample }\end{array}$} \\
\hline & & $\begin{array}{l}\text { Vol- } \\
\text { ume }\end{array}$ & Purity & Kind $c$ & $\begin{array}{l}\text { A zeotrope- } \\
\text { forming } \\
\text { substance }\end{array}$ & $\begin{array}{l}\text { A mount } \\
\text { of hydro- } \\
\text { carbon } \\
\text { in the } \\
\text { azeo- } \\
\text { tropic } \\
\text { distil- } \\
\text { late- }\end{array}$ & $\begin{array}{c}\text { Dis- } \\
\text { tilling } \\
\text { col- } \\
\text { umn } \\
\text { num- } \\
\text { ber } f\end{array}$ & $\begin{array}{l}\text { Num- } \\
\text { ber of } \\
\text { theo- } \\
\text { retical } \\
\text { plates } f \\
\text { (ap- } \\
\text { prox.) }\end{array}$ & $\begin{array}{l}\text { Reflux } \\
\text { ratio } f \\
\text { (ap- } \\
\text { prox.) }\end{array}$ & $\begin{array}{c}\text { Rate } \\
\text { of col- } \\
\text { lection } \\
\text { of dis- } \\
\text { tillate }\end{array}$ & $\begin{array}{l}\text { Results } \\
\text { plotted } \\
\text { in } \\
\text { figure }\end{array}$ & $\begin{array}{l}\text { A PI- } \\
\text { Stand- } \\
\text { ard }\end{array}$ & $\begin{array}{l}\text { API- } \\
\text { NBS }\end{array}$ \\
\hline
\end{tabular}

ALKYLCYCLOPENTANES

\begin{tabular}{|c|c|c|c|c|c|c|c|c|c|c|c|c|c|}
\hline \multirow[t]{2}{*}{ Ethylcyclopentane (B) ...... } & \multirow[t]{2}{*}{$\begin{array}{l}\text { APIRP45 } \\
\text { Penn State.......... }\end{array}$} & $\begin{array}{r}\text { Liters } \\
3.47 \\
2.90\end{array}$ & $\left.\begin{array}{c}\text { Mole \% } \\
99.47 \\
96.29\end{array}\right\}$ & Reg..... & \multirow[b]{2}{*}{ Ethanol } & $\begin{array}{c}\% \text { by } \\
\text { volume }\end{array}$ & 15 & 125 & $110 / 1$ & $\begin{array}{r}m l / h r \\
14.0\end{array}$ & 21 & $m l$ & \multirow[t]{2}{*}{$m l$} \\
\hline & & 2.80 & 99.86 & Azeo ..... & & 52 & 13 & 130 & $155 / 1$ & 8.0 & 22 & 1400 & \\
\hline 1,1-Dimethylcyclopentane _- & Penn State & 1.82 & 99.958 & ... do $\ldots . .$. & ... do ...... & 64 & 9 & 135 & $165 / 1$ & 4. 5 & 23 & 1126 & 260 \\
\hline $\begin{array}{l}\text { cis-1,2-Dimethylcyelopen- } \\
\text { tane. }\end{array}$ & ..... do & 1.36 & 99.90 & ... do $\ldots . .$. & ... do ...... & 53 & 9 & 135 & $165 / 1$ & 4. 5 & 24 & 780 & 120 \\
\hline $\begin{array}{l}\text { trans-1,2-Dimethyleyclopen- } \\
\text { tane. }\end{array}$ & ..... do .... & 1.46 & 99.68 & ... do .... & ... do .... & 61 & 4 & 200 & $160 / 1$ & 4.5 & 25 & 906 & 138 \\
\hline \multirow{3}{*}{$\begin{array}{l}\text { trans-1,3-Dimethyleyclopen- } \\
\text { tane. }\end{array}$} & APIRP45 - & 3.00 & 73.6 & Reg..... & & & 4 & 200 & $145 / 1$ & 5. 0 & 26 & & \\
\hline & & 1.83 & 90.0 & Azeo ..... & Methanol & 55 & 10 & 135 & $165 / 1$ & 4. 5 & 27 & & ... \\
\hline & & 1.13 & 94.6 & $\ldots$ do $\ldots . .$. & Ethanol & 63 & 4 & 200 & $180 / 1$ & 4. 0 & 28 & 570 & 102 \\
\hline \multirow[t]{3}{*}{$n$-Propylcyclopentane....... } & ..... do ... & 1. 30 & 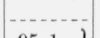 & Reg..... & (............ & $\cdots$ & 4 & 200 & $145 / 1$ & 5. 0 & 29 & ${ }^{k} 333$ & ${ }^{l} 75$ \\
\hline & ..... do & $\begin{array}{r}0.30 \\
m 2.70\end{array}$ & $\left.\begin{array}{l}95.1 \\
97.06\end{array}\right\}$ & ... do . . . & & & 13 & 130 & $155 / 1$ & 8.0 & 30 & 972 & 275 \\
\hline & $\ldots$ do $\ldots . . . .$. & $\begin{array}{c}n 0.44 \\
5.71\end{array}$ & 98.67 & ... do _. . & & & 10 & 135 & & & & & \\
\hline \multirow{2}{*}{$\begin{array}{l}\text { 1, 1,2-Trimethylcyclopen- } \\
\text { tane. }\end{array}$} & Penn State & 1.32 & - n..... & Azeo & Isoprop & 33 & 9 & 135 & $\begin{array}{l}145 / 1 \\
165 / 1\end{array}$ & $\begin{array}{l}5.0 \\
4.5\end{array}$ & $\begin{array}{l}31 \\
32\end{array}$ & 1180 & 370 \\
\hline & & 1.07 & & Reg..... & & & 3 & 100 & $150 / 1$ & 2.0 & 33 & 680 & 115 \\
\hline \multirow{5}{*}{$\begin{array}{l}\text { 1,1,3-Trimethylcyclopen- } \\
\text { tane. }\end{array}$} & Gulf-Mellon & 0.60 & -. & $\ldots$ do $\ldots . .$. & $\cdots$ & $\ldots$ & 3 & 100 & $120 / 1$ & 2. 5 & 34 & & 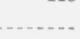 \\
\hline & APIRP45 & $\begin{array}{r}0.50 \\
\circ 1.80\end{array}$ & & ... do & & & 12 & 135 & $185 / 1$ & 4. 0 & 35 & & \\
\hline & & 1.57 & & Azeo .... & Me. Cell.. & 80 & 12 & 135 & $165 / 1$ & 4. 5 & 36 & & \\
\hline & & 0.80 & & ... do .... & Isoprop ... & 46 & 7 & 130 & $145 / 1$ & 8.5 & 37 & & \\
\hline & & $\begin{array}{c}0.51 \\
\triangleright 0.52\end{array}$ & & .... do & ... do . & 46 & 4 & 200 & $180 / 1$ & 4. 0 & 38 & 460 & 65 \\
\hline \multirow{3}{*}{$\begin{array}{l}\text { cis, cis, trans-1,2,4-Trimeth- } \\
\text { ylcyclopentane. }\end{array}$} & Penn State & 3.00 & & Reg ..... & & $\cdots$ & 4 & 200 & $180 / 1$ & 4.0 & 39 & & \\
\hline & & 1.86 & 98.5 & Azeo .... & Isoprop ... & 30 & 11 & $(u)$ & $160 / 1$ & 4. 5 & 40 & & \\
\hline & & 1.28 & 98.9 & ... do .... & ... do . . . & 30 & 4 & 200 & $145 / 1$ & 5.0 & 41 & 515 & 81 \\
\hline \multirow{2}{*}{$\begin{array}{l}\text { cis, trans, cis-1,2,4-Trimeth- } \\
\text { ylcyclopentane. }\end{array}$} & ..... do . & 1.80 & 98.5 & Reg & - . . . & (......... & 2 & 100 & $150 / 1$ & 2. 0 & 42 & $\ldots$ & \\
\hline & & 1.42 & 99. 66 & Azeo .... & Ethanol & 48 & 9 & 135 & $165 / 1$ & 4.5 & 43 & 790 & 125 \\
\hline
\end{tabular}

ALKYLCYCLOHEXANES

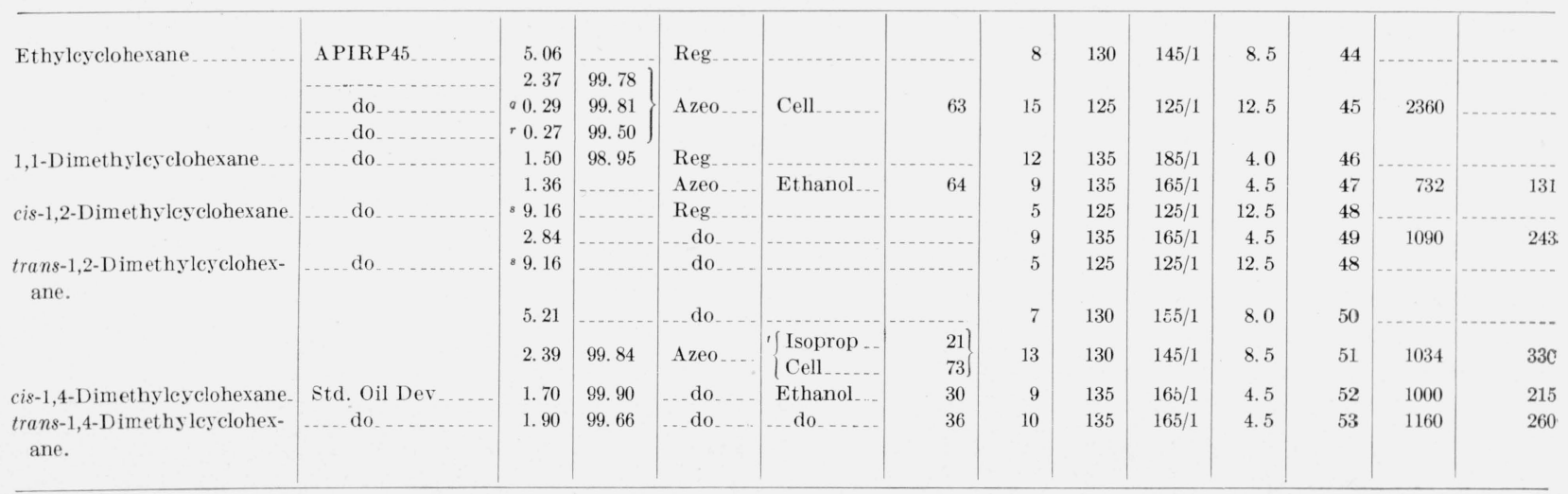

Fontnotes on page 56. 
a $(B)$ following the name of a compound indicates that for the API-NBS series, it is a second (and usually slightly purer) sample of the given compound, the first sample of which is labeled $(A)$. See reference [6].

$b$ The abbreviations represent the following laboratories: APIRP45; American Petroleum Institute Research Project 45 (formerly the American Petroleum Institute Hydrocarbon Research Project) at the Ohio State University, Columbus, Ohio. Penn State; Hydrocarbon Laboratory at the Pennsylvania State College, State College, Pa. NACA; National Advisory Committee for Aeronautics, Aeronautical Engine Research Laboratory, Cleveland, Ohio, and the Automotive Section, National Bureau of Standards Washington, D. C. Std. Oil Dev.; Standard Oil Development Co., Elizabeth, New Jersey. Gulf-Mellon; Gulf Oil Co. Fellowship at the Mellon Institute of Industrial Research, Pittsburgh, Pennsylvania. APIRP6; American Petroleum Institute Research Project 6 at the National Bureau of Standards, Washington, D. C.

c The abbreviations are Azeo., azeotropic; Reg., regular.

$d$ The abbreviations are Cell., Cellosolve (ethylene glycol monoethyl ether); Me. Cell., methyl Cellosolve (ethylene glycol monomethyl ether); Me. Carb., methyl Carbitol (diethylene glycol monomethyl ether); Isoprop., isopropanol.

- Approximate value obtained from the actual volume of hydrocarbon recovered by extracting the azeotrope-forming substance with water in separatory funnels.

$f$ See reference [4] for further details.

- Obtained by distillation from an Oklahoma petroleum.

\section{Purification}

The procedure followed in the process of purification and determination of purity was the same as that described in the previous report [1].

In addition to the name of the laboratory supplying the starting materials, table 1 and its footnotes give complete information for each distillation for each of the compounds.

Details of the distillation apparatus and operations are described in reference [4].

Figures 1 to 53, inclusive, show graphically the results of the distillations listed in table 1 . These figures give, as a function of volume of hydrocarbon distillate, the refractive index $\left(n_{D}\right.$ at $25^{\circ}$ $\mathrm{C}$, to $\left.\pm 0.0001^{\circ}\right)$, the boiling point of the distillate (at the controlled pressure of $724.5 \mathrm{~mm}$ $\mathrm{Hg}$, to $\pm 0.01^{\circ} \mathrm{C}$ ), the freezing point of selected fractions of hydrocarbon distillate (in air at $1 \mathrm{~atm}$, usually with a precision near $\pm 0.003^{\circ} \mathrm{C}$ ), and the purity of the hydrocarbon distillate. The letters $W, X, Y$, and $Z$ indicate the disposition of the material, as follows: $W$, returned to the laboratory supplying the material; $X$, blended for redistillation; $Y$, used for the API-Standard material; $Z$, used for the API-NBS material.

As demonstrated in the previous report, the blending of fractions of distillate for the prepara-
${ }^{h}$ Obtained by distillation from commercial "pentenes" alkylates (pentenes + isobutane).

i This starting material consisted of a blend of 2,2,3,4-tetramethylpentane (approximately 25\%), "S-4" reference fuel ("isooctane") (approximately $66 \%$ ), and $n$-heptane (approximately $9 \%$ ).

$i$ Calculated from the measured freezing points of two separate lots which were blended together for this charge.

${ }_{k}$ The total volume of the API-Standard sample was $1,305 \mathrm{ml}$.

? The total volume of the API-NBS sample was $350 \mathrm{ml}$.

${ }_{m}$ This is a second lot of $n$-propylcyclopentane supplied by API Research Project 45.

$n$ Fractions 272 to 292 from the distillation of isopropylcyclopentane in column 10 (see figure 31 ).

- This second lot of 1,1,3-trimethylcyclopentane was supplied by the API Research Project 45.

v Fractions 41 to 60 from the azeotropic distillation in column 12 (see fig. 36)

a This is a second lot of ethylcyclohexane supplied by the API Research Project 45.

- This is a third lot of ethylcyclohexane supplied by the API Research Project 45 .

- Both cis and trans 1,2-dimethylcyclohexane were obtained from this material (see fig. 48).

t The distillation was begun with isopropanol as the azeotrope-forming substance, but because of the relatively small percentage of hydrocarbon in the azeotropic distillate, cellosolve was added to complete the distillation.

w The number of theoretical plates for this column was not determined.

tion of material of the highest purity can be done safely only on the basis of freezing points of selected fractions. An example of a case where the purest material is at the very beginning of a distillation is shown in figure 27 on trans-1,3dimethylcyclopentane, and an example of a case where the purest material is at the end of the distillation is shown in figure 17 for sec-butylbenzene.

\section{Freezing Points, Cryoscopic Constants, and Purity}

Table 2 gives the following information for each of the 29 compounds, except as otherwise indicated: The kind of time-temperature curves, whether freezing or melting, used to determine the freezing point [7]; the freezing point of the actual sample, in air at $1 \mathrm{~atm}$ [7], for both the APIStandard and API-NBS lots; the calculated value of the freezing point for zero impurity [7]; the value of the cryoscopic constant, determined from the lowering of the freezing point on the addition of a known amount of an appropriate impurity [7]; and the resulting calculated amount of impurity in the API-Standard and the APINBS material. 
TABLE 2.-Freezing points and purity of 29 API-Standard and API-NBS hydrocarbons

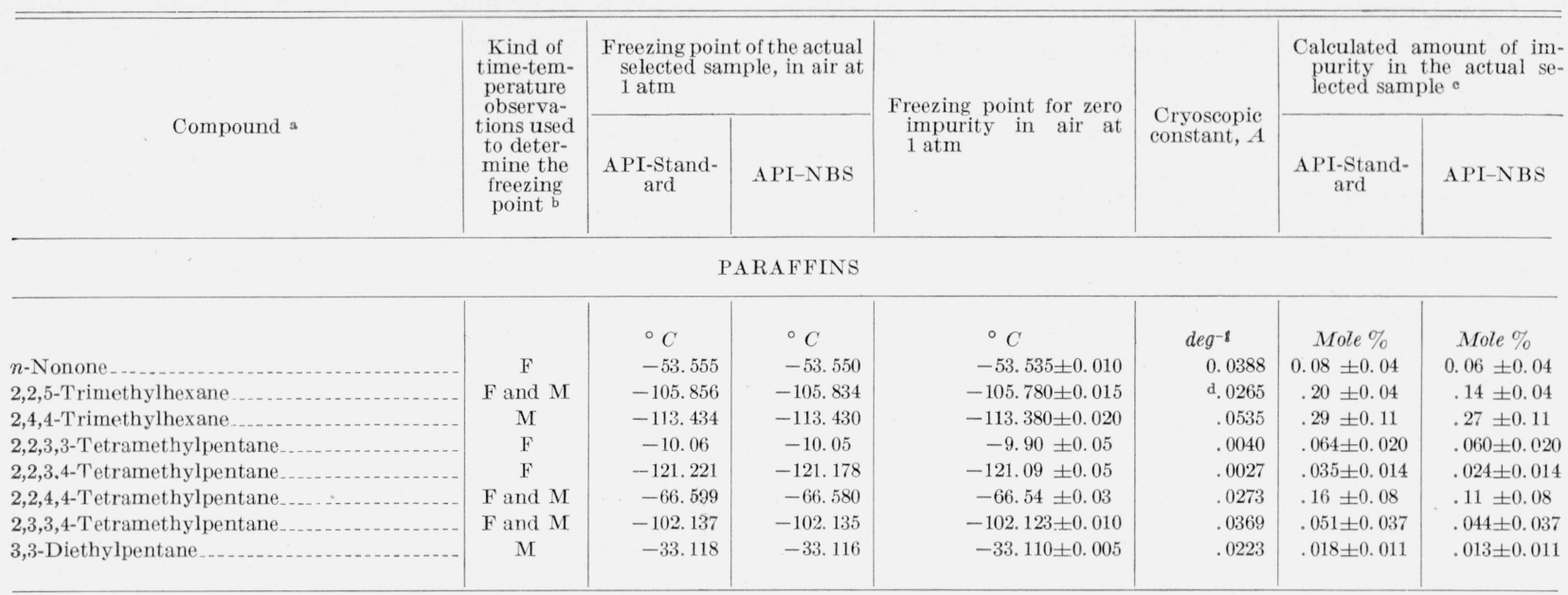

ALKYLBENZENES

$n$-Butylbenzene $(B)$

Isobutylbenzene $(B)$

sec-Butylbenzene $(B)$

tert-Butylbenzene $(B)$

\begin{tabular}{l|l} 
& \\
-88.000 & -87.993 \\
-51.523 & -51.520 \\
-75.511 & -75.493 \\
-57.876 & -57.876
\end{tabular}

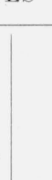

\begin{tabular}{l|r|r|r} 
& & & \\
$-87.970 \pm 0.020$ & $e(0.0385)$ & $0.12 \pm 0.08$ & $0.09 \pm 0.08$ \\
$-51.48 \pm 0.03$ & .0306 & $.13 \pm 0.09$ & $.112 \pm 0.09$ \\
$-75.470 \pm 0.020$ & .0303 & $.12 \pm 0.06$ & $.07 \pm 0.06$ \\
$-57.850 \pm 0.015$ & .0218 & $.06 \pm 0.03$ & $.06 \pm 0.03$ \\
& & &
\end{tabular}

\section{ALKYLCYCLOPENTANES}

\begin{tabular}{|c|c|c|c|c|c|c|c|}
\hline Ethylcyclopentane_. & M & -138.454 & -138.452 & $-138.435 \pm 0.010$ & 0.0303 & $0.06 \pm 0.03$ & $0.05 \pm 0.03$ \\
\hline 1,1-Dimethylcyciopentane...... & $\mathrm{F}$ & -69.802 & -69.802 & $-69.73 \pm 0.04$ & d. 004 & $.03 \pm 0.02$ & $.03 \pm 0.02$ \\
\hline crs-1,2-Dimethylcyclopentane_... & $\mathrm{F}$ & -53.927 & -53.910 & $-53.85 \pm 0.04$ & .0042 & $.031 \pm 0.016$ & $.025 \pm 0.016$ \\
\hline trans-1,2-Dimethyleyclopentane & $\mathrm{M}$ & -117.63 & -117.61 & $-117.57 \pm 0.03$ & $\mathrm{e}(.0320)$ & $.19 \pm 0.10$ & $.13 \pm 0.10$ \\
\hline trans-1,3-Dimethyleyclopentane ..... & M & -133.767 & -133.758 & $-133.680 \pm 0.020$ & .0455 & $.39 \pm 0.09$ & $.35 \pm 0.09$ \\
\hline$n$-Propylcyclopentane & $\mathrm{M}$ & -117.379 & -117.378 & $-117.340 \pm 0.020$ & .0511 & $.20 \pm 0.10$ & $.19 \pm 0.10$ \\
\hline Isopropylcyclopentane & $\mathrm{M}$ & -111.433 & -111.431 & $-111.375 \pm 0.020$ & .0346 & $.20 \pm 0.07$ & $.19 \pm 0.07$ \\
\hline $1,1,2$-Trimethylcyclopentane $\ldots .$. & $\mathrm{F}$ & -21.69 & -21.68 & $-21.64 \pm 0.03$ & .0030 & $.015 \pm 0.009$ & $.012 \pm 0.009$ \\
\hline 1,1,3-Trimethylcyclopentane $\ldots \ldots$. & $\mathrm{M}$ & -142.56 & -142.55 & $-142.44 \pm 0.08$ & .040 & $.48 \pm 0.32$ & $.44 \pm 0.32$ \\
\hline cis, cis, $\operatorname{trans-1,2,4-Trimethylcyclopentane} \ldots$ & M & -132.66 & -132.64 & $-132.55 \pm 0.06$ & .0385 & $.42 \pm 0.23$ & $.35 \pm 0.23$ \\
\hline cis, trans, cis-1,2,4-Trimethylcyclopentane .... & M & -130.85 & -130.84 & $-130.78 \pm 0.03$ & .0343 & $.24 \pm 0.10$ & $.21 \pm 0.10$ \\
\hline
\end{tabular}

\section{ALKYLCYCLOHEXANES}

\begin{tabular}{|c|c|c|c|c|c|c|c|}
\hline Ethylcyclohexane. & M & -111.335 & & $-111.300 \pm 0.020$ & 0.0384 & $0.13 \pm 0.08$ & \\
\hline 1,1-Dimethylcyclohexane...... & $\mathrm{F}$ and $\mathrm{M}$ & -33.839 & -33.654 & $-33.54 \pm 0.05$ & .0665 & $.19 \pm 0.03$ & $0.07 \pm 0.03$ \\
\hline cis-1,2-Dimethylcyclohexane.. & M & -50.047 & -50.034 & $-50.00 \pm 0.03$ & .0051 & $.024 \pm 0.015$ & $.017 \pm 0.015$ \\
\hline trans-1,2-Dimethylcyclohexane. & M & -88.203 & -88.203 & $-88.180 \pm 0.020$ & .0365 & $.08 \pm 0.07$ & $.08 \pm 0.07$ \\
\hline cis,1,4-Dimethyleyclohexane & M & -87.445 & -87.445 & $-87.425 \pm 0.015$ & .0283 & $.06 \pm 0.04$ & $06 \pm 0.04$ \\
\hline trans-1,4-Dimethylcyclohexane & $\mathrm{F}$ and $\mathrm{M}$ & -36.976 & -36.964 & $-36.92 \pm 0.03$ & .0259 & $.14 \pm 0.08$ & $.11 \pm 0.08$ \\
\hline
\end{tabular}

a $(B)$ following the name of a compound indicates that, for the API-NBS series, it is a second (and usually slightly purer) sample of the given compound, the first sample of which is labeled $(A)$. See reference [6].

b $\mathrm{F}$ indicates freezing and $\mathrm{M}$ indicates melting. See reference [7] for experimental details and the definition of the cryoscopic constant.

- The values in this column were calculated as described in reference[7], using the values of the cryoscopic constants and freezing points for zero im purity given in the preceding columns.

d This cryoscopic constant was determined by the procedure given on page 371 of reference [7].

e Not determined in this investigation. From the " $z$ " tables of the American Petroleum Institute Research Project 44 [8]. 
Grateful acknowledgment is made to the organizations and individuals listed in section II of this report for their contributions of materials for use in this work.

\section{References}

[1] A. J. Streiff, E. T. Murphy, V. A. Sedlak, C. B. Willingham, and F. D. Rossini, J. Research NBS 37, 331 (1946) RP1752.

[2] R. L. Demmerle. Chem. Eng. News 15, (1946).

[3] Tech. News Bul. NBS No. 350 (June 1946).

[4] B. J. Mair, D. J. Termini, C. B. Willingham, and F. D. Rossini, J. Research NBS 37, 229 (1946) RP1744.
[5] A. R. Glasgow, Jr., E. T. Murphy, C. B. Willingham, and F. D. Rossini, J. Research NBS 37, 141 (1946) RP1734.

[6] C. B. Willingham and F. D. Rossini, J. Research NBS 37, 15 (1946) RP1724.

[7] A. R. Glasgow, Jr., A. J. Streiff, and F. D. Rossini, J. Research NBS 35, 355 (1945) RP1676.

[8] American Petroleum Institute Research Project 44 at the National Bureau of Standards. Selected values of properties of hydrocarbons. Heat and entropy of fusion, freezing points, and cryoscopic constants. Tables $1 z, 2 z, 3 z, 5 z$, and $6 z$.

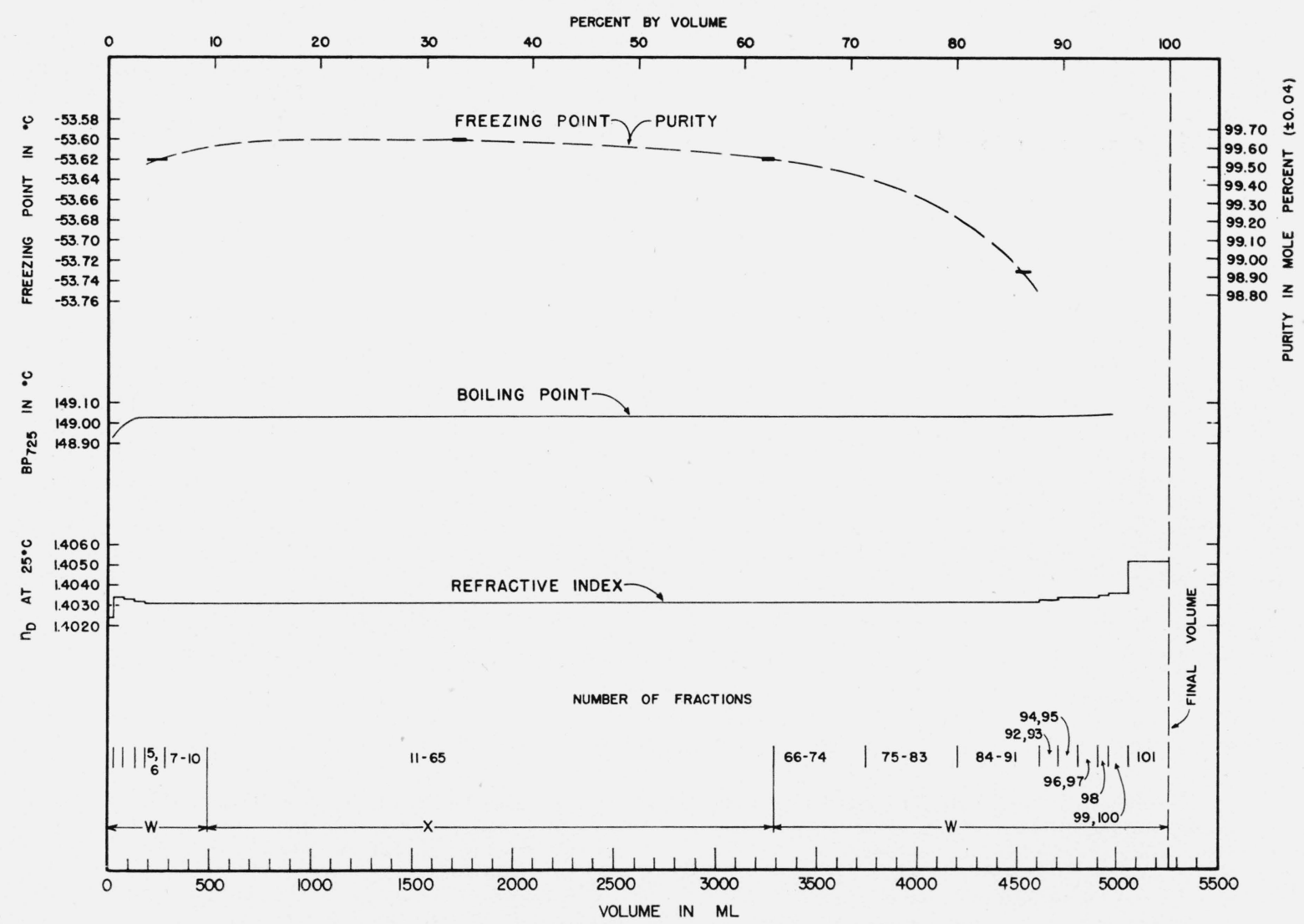

Figure 1.-Results of the first distillation of n-nonane.

Regular distillation at $725 \mathrm{~mm} \mathrm{Hg}$ in still $14(8 / 28 / 45$ to $9 / 15 / 45)$. 


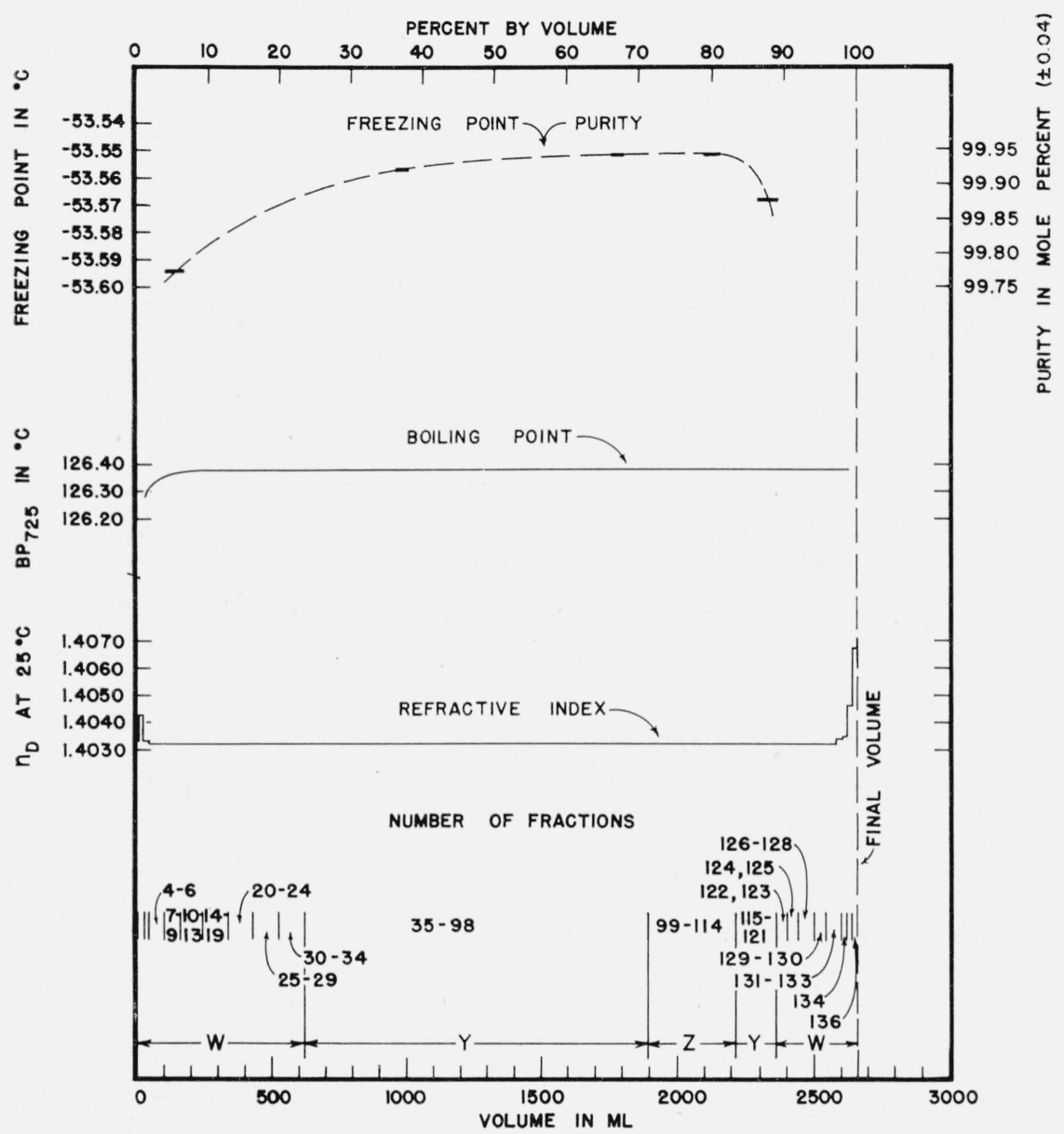

FiguRE 2.-Results of the second and final distillation of n-nonane.

Azeotropic distillation with ethylene glycol moncethyl other at $725 \mathrm{~mm} \mathrm{Ho}$ in still 13 (10/13/45 to 11/14/45). 


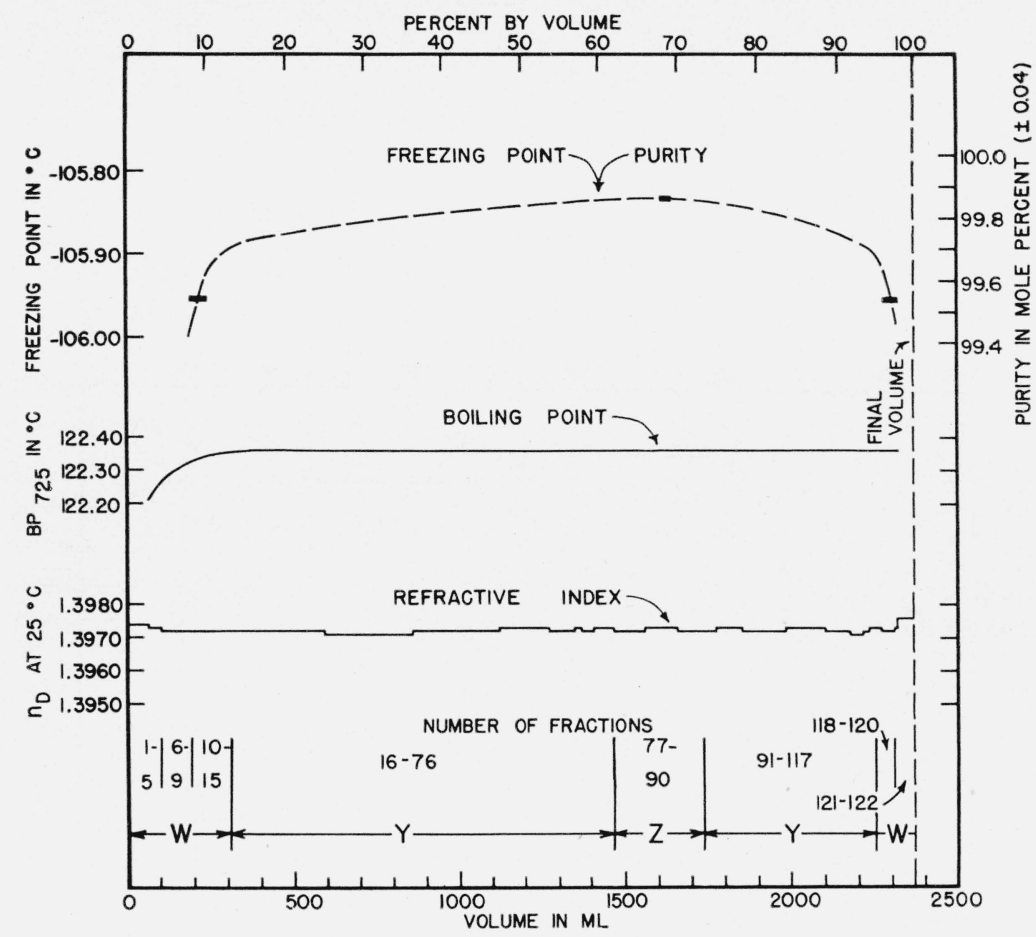

FIGURE 3.-Results of the first and only distillation of 2,2,5-trimethylhexane. Regular distillation at $725 \mathrm{~mm} \mathrm{Hg}$ in still $3(6 / 26 / 44$ to $8 / 6 / 44)$.

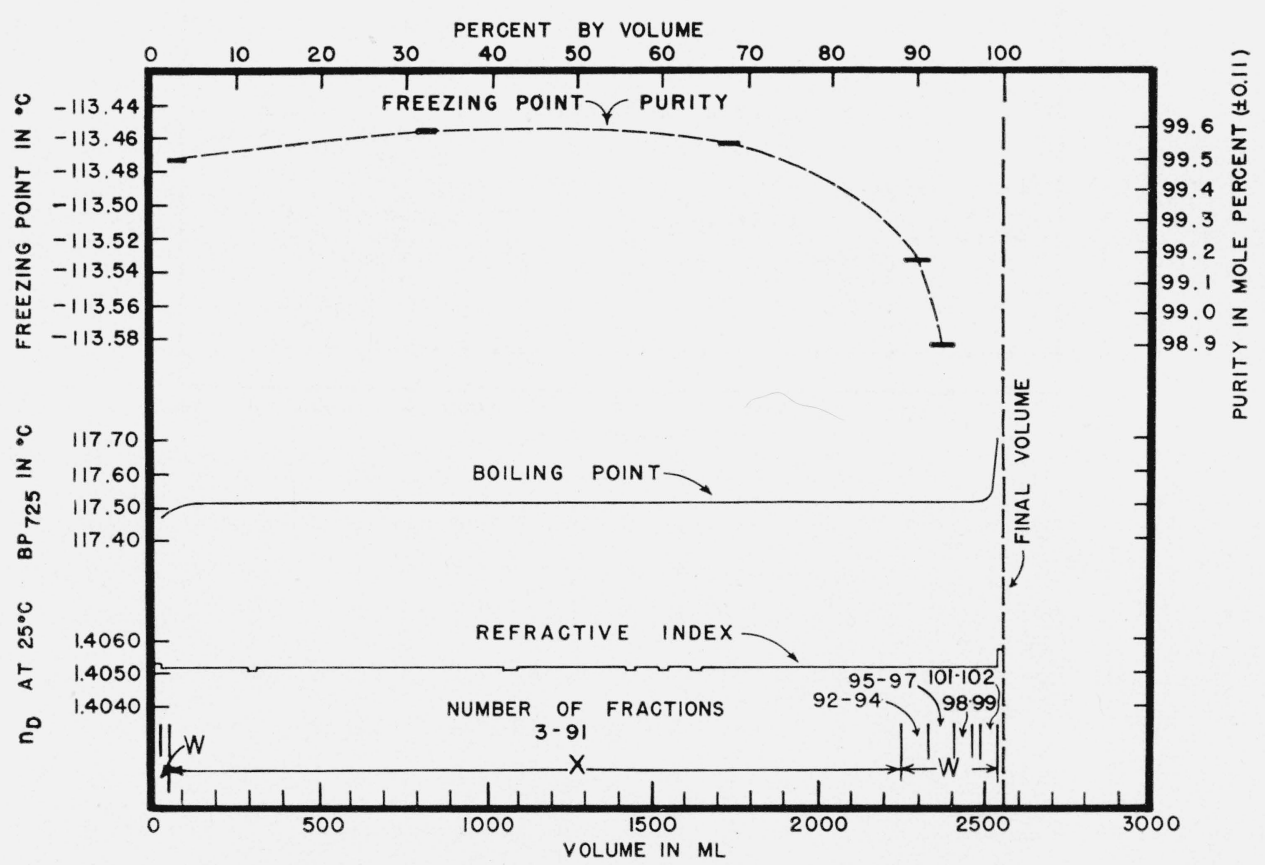

FIGURE 4.-Results of the first distillation of 2,4,4-trimethylhexane.

Azeotropic distillation with ethylene glycol monoethyl ether at $725 \mathrm{~mm} \mathrm{Hg}$ in still 13 (11/16/44 to 12/6/44). 


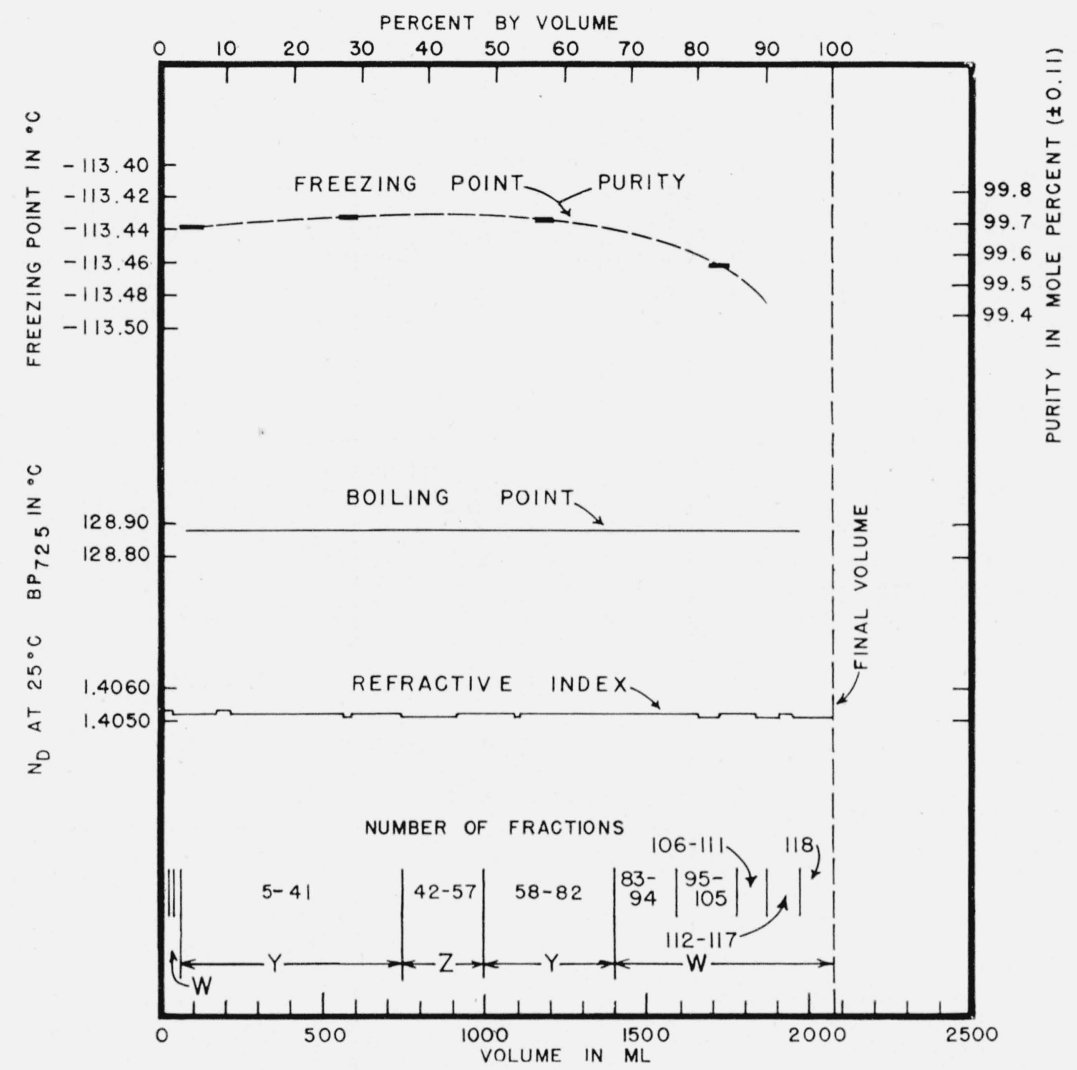

FIGURE 5.-Results of the second and final distillation of 2,4,4-trimethylhexane. Regular distillation at $725 \mathrm{~mm} \mathrm{Hg}$ in still 12 (6/21/45 to $7 / 13 / 45)$. 


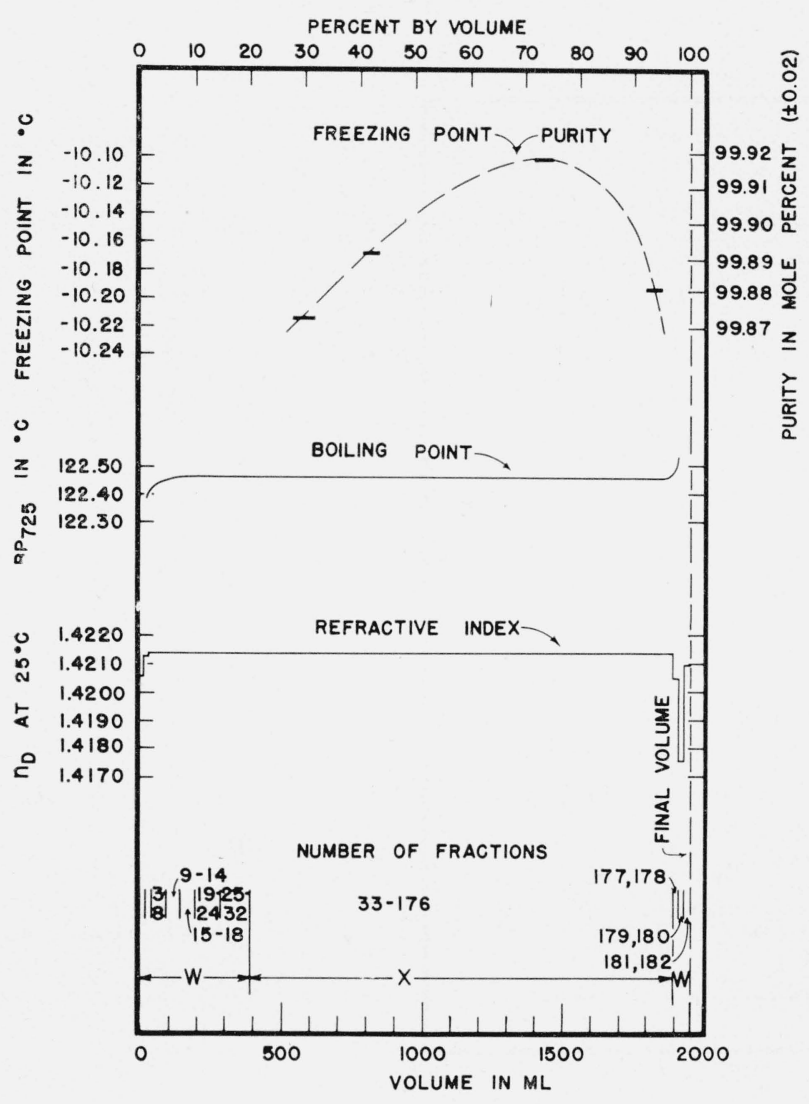

Figure 6.-Results of the first distillation of 2,2,3,3-tetramethylpentane.

Azeotropic distillation with ethylene glycol monoethyl ether at $725 \mathrm{~mm} \mathrm{Hg}$ in still $10(11 / 23 / 45$ to $12 / 31 / 45)$.

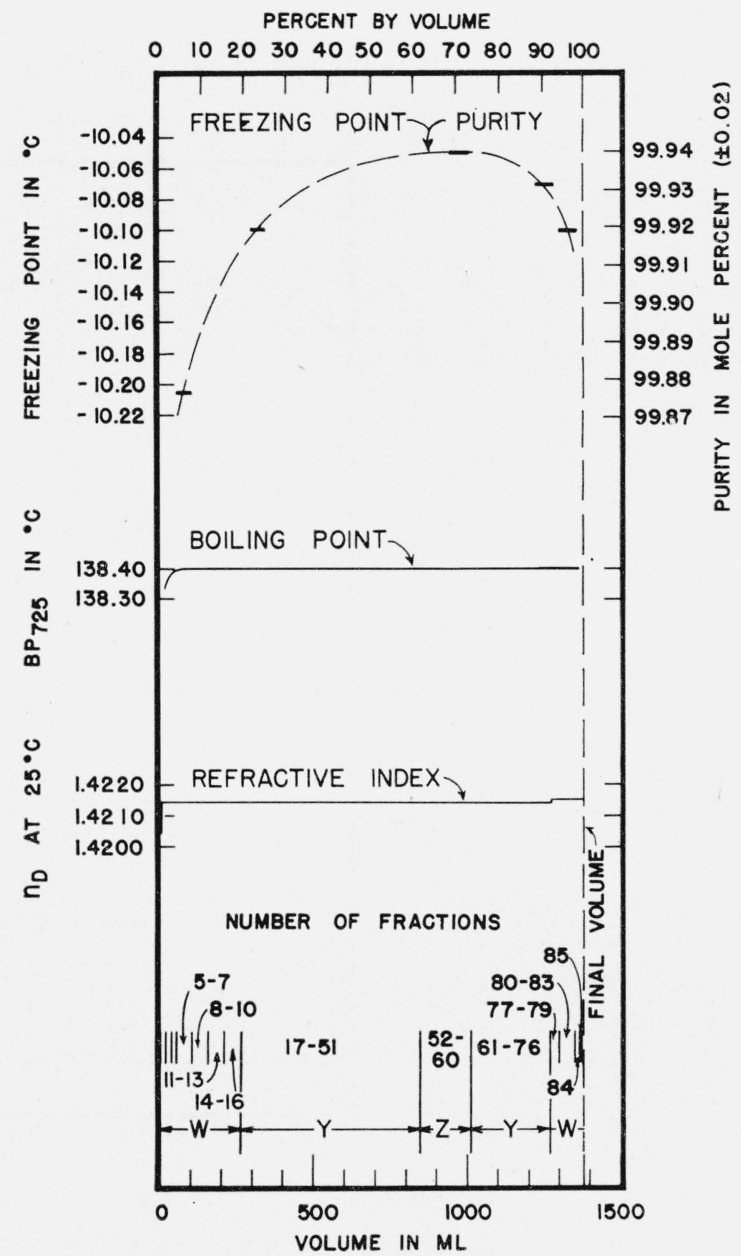

FIGURE 7.-Results of the second and final distillation of 2,2,3,3-tetramethylpentane.

Regular distillation at $725 \mathrm{~mm} \mathrm{Hg}$ in still $11 \mathrm{~A}(2 / 20 / 46$ to $3 / 14 / 46)$ 


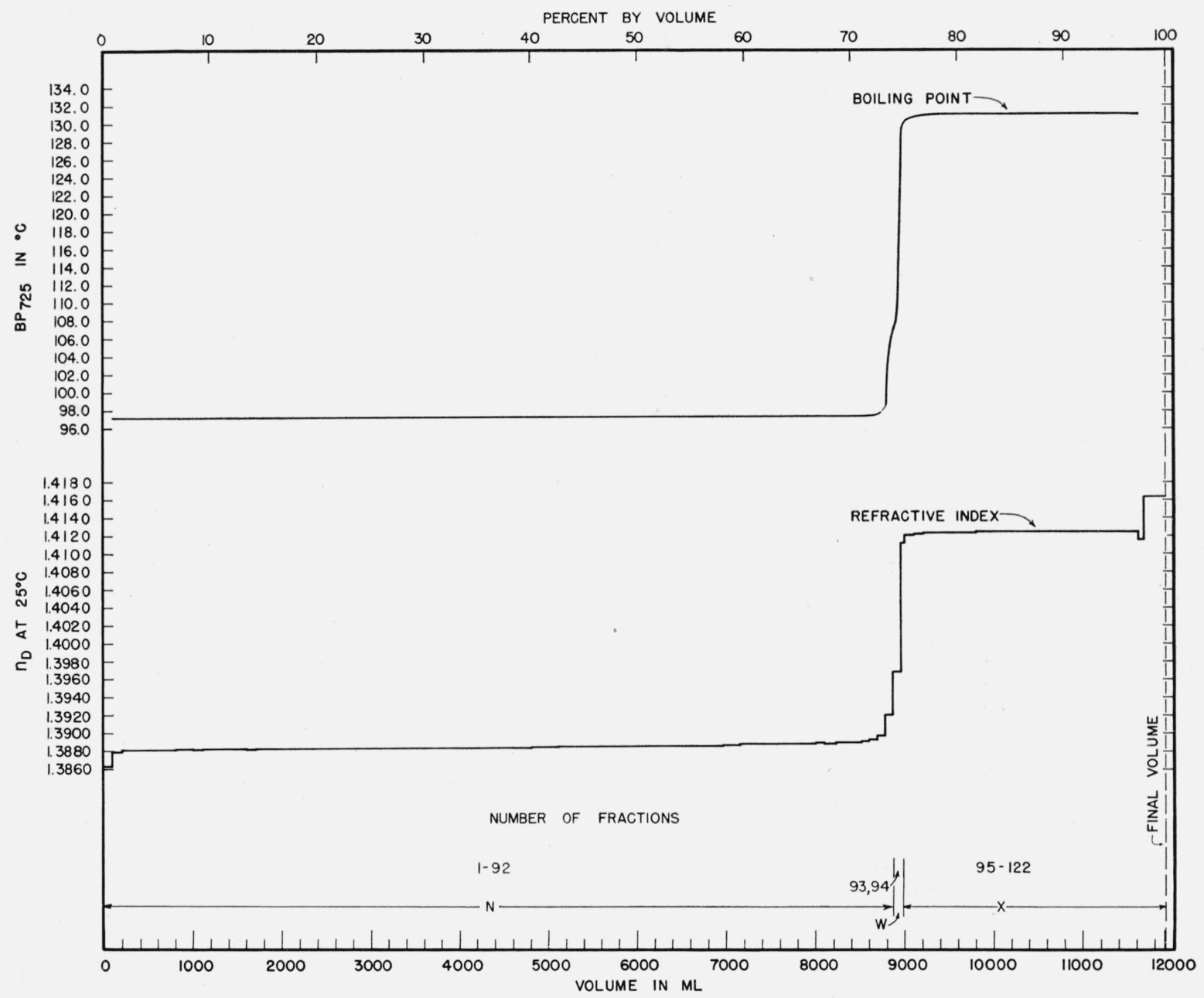

Figure 8.-Results of the first distillation of 2,2,3,4-tetramethylpentane.

Regular distillation at $725 \mathrm{~mm} \mathrm{Hg}$ in still $6(7 / 27 / 45$ to 9/11/45).

The portion marked "N" was discarded. See footnote $i$ of table 1 . 


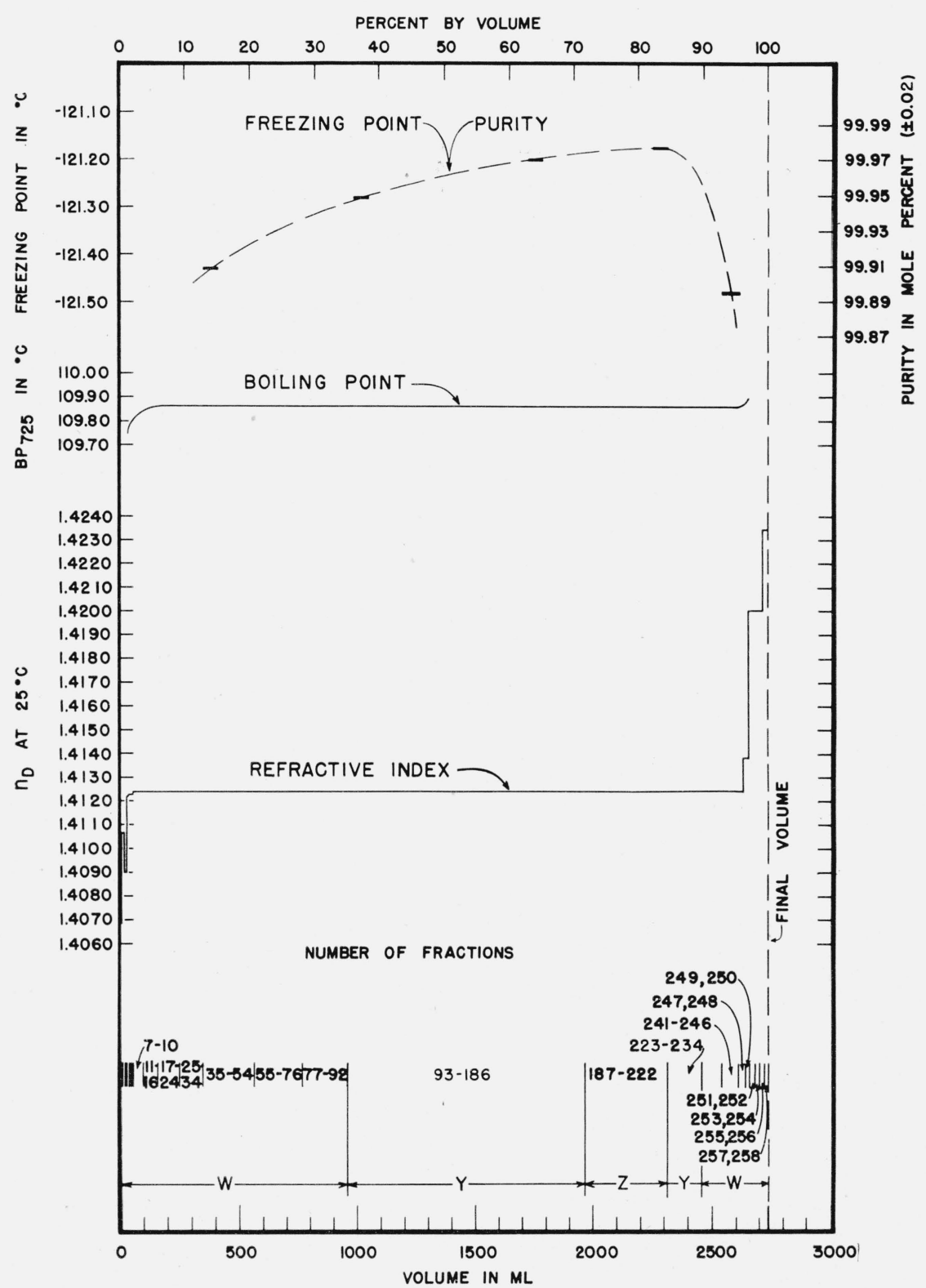

FiguRE 9.-Results of the second and final distillation of 2,2,3,4-tetramethylpentane. Azeotropic distillation with ethylene glycol monomethyl ether at $725 \mathrm{~mm} \mathrm{Hg}$ in still 10 (9/27/45 to 11/19/45). 


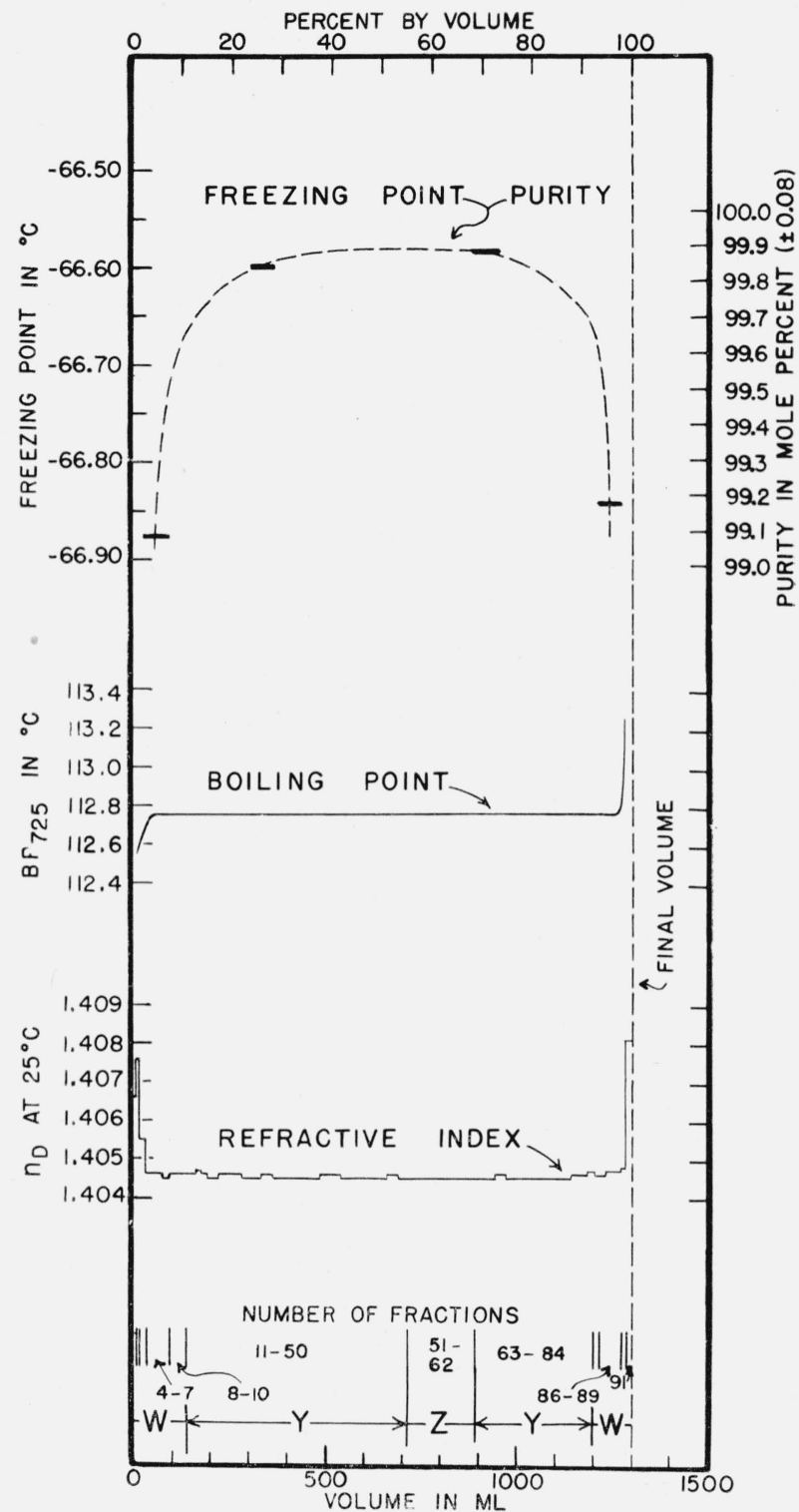

FIGURE 10.-Results of the first and only distillation of 2,2,4,4-tetramethylpentane.

Azeotropic distillation with ethylene glycol monoethyı ether at $725 \mathrm{~mm} \mathrm{Hg}$ in still $4(9 / 11 / 44$ to $9 / 29 / 44)$. 


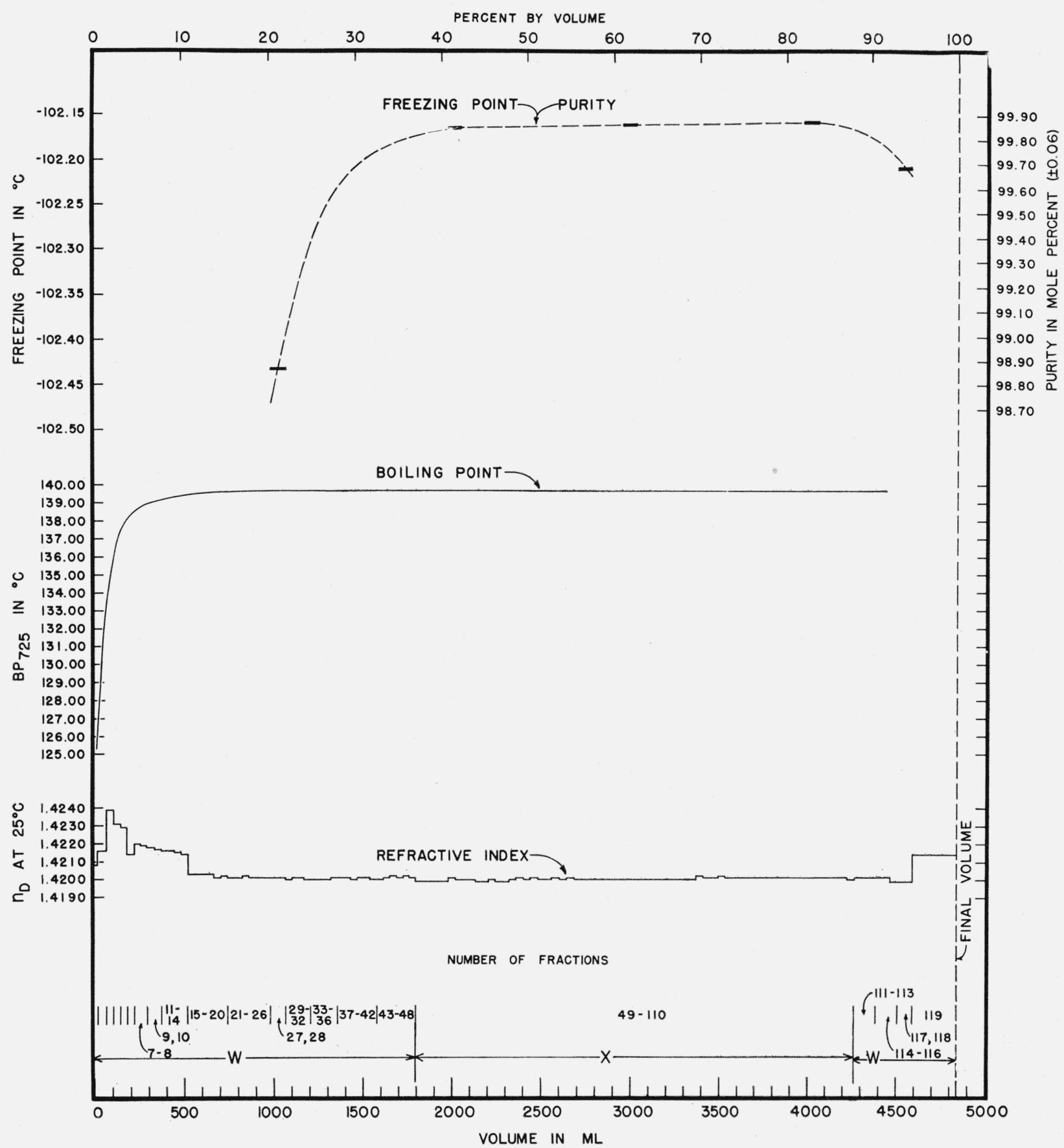

FIGURE 11.-Results of the first distillation of 2,3,3,4-tetramethylpentane. Regular distillation at $725 \mathrm{~mm} \mathrm{Hg}$ in still $8(7 / 4 / 45$ to $7 / 31 / 45)$. 


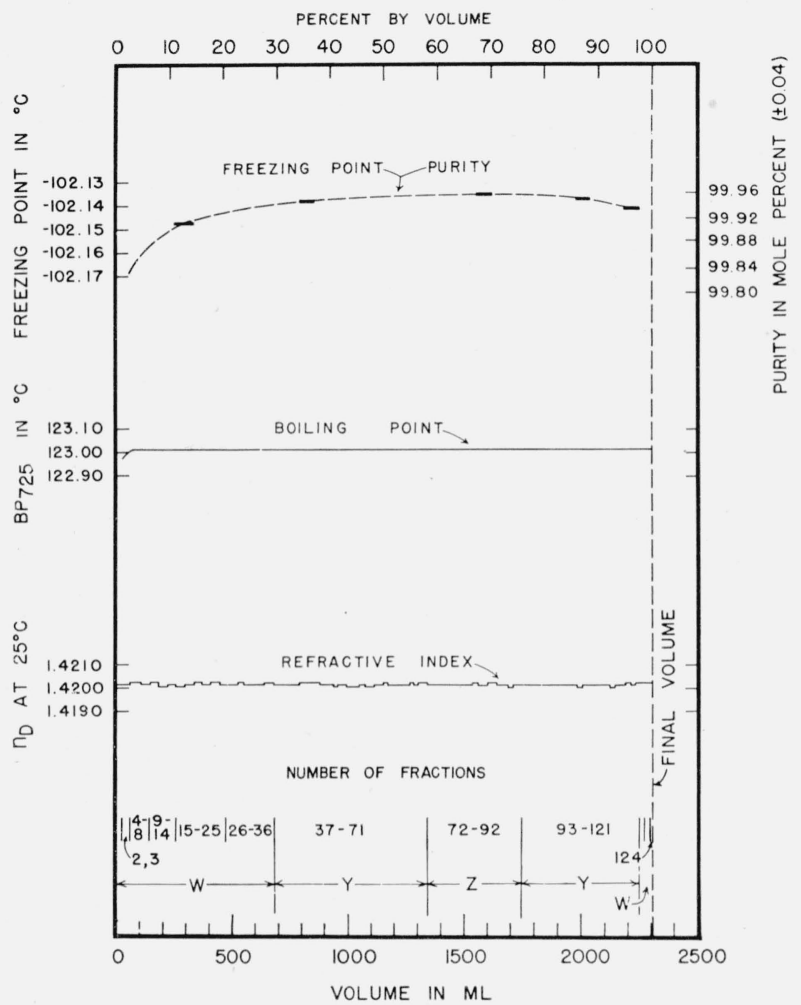

FIgURE 12.-Results of the second and final distillation of 2,3,3,4-tetramethylpentane.

Azeotropic distillation with ethylene glycol monoethyl ether at $725 \mathrm{~mm} \mathrm{Hg}$ in still $8(9 / 18 / 45$ to $10 / 16 / 45)$. 


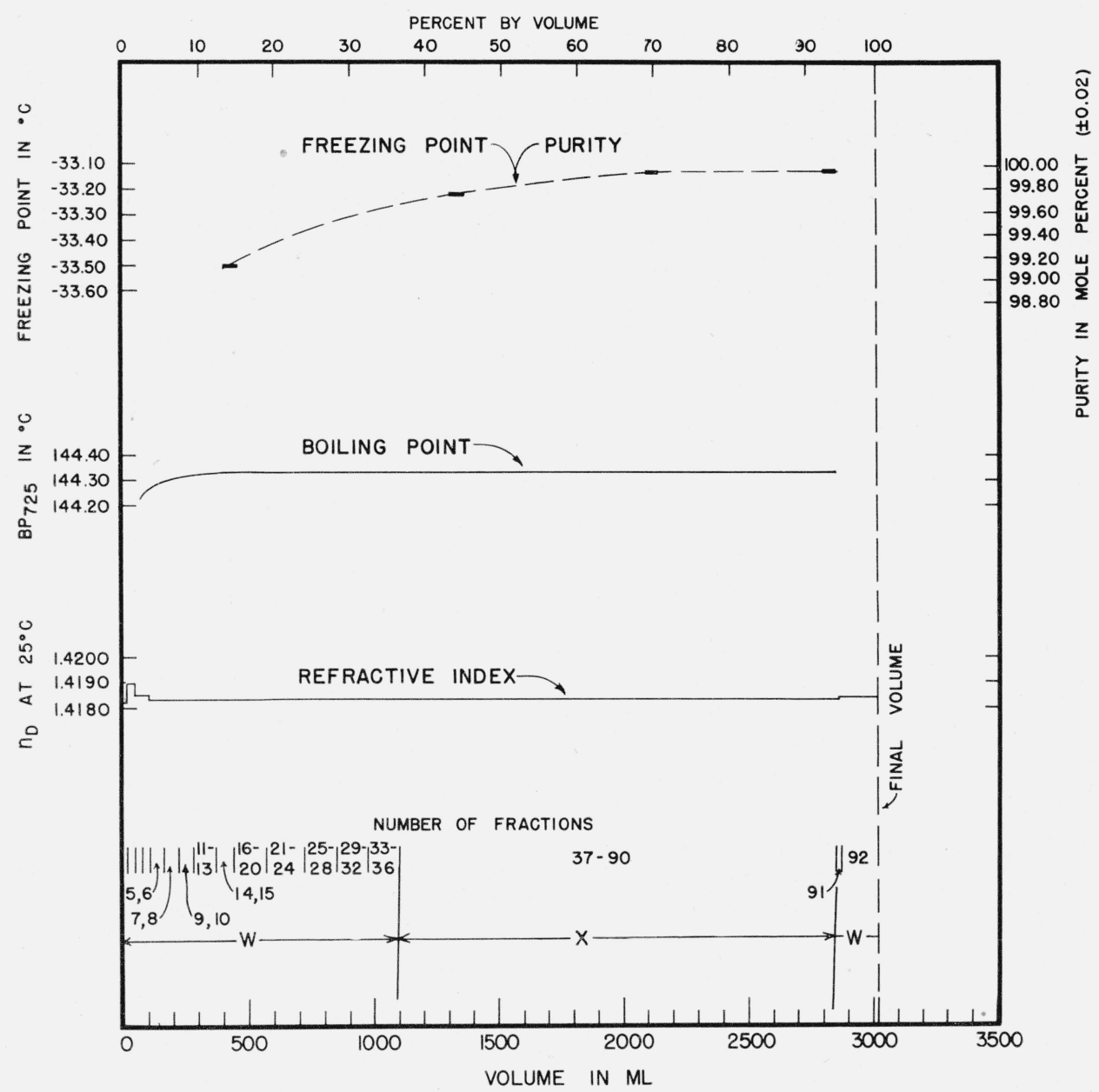

FIGURE 13.--Results of the first distillation of 8,3-diethylpentane. Regular distillation at $725 \mathrm{~mm} \mathrm{Hg}$ in still $13(8 / 13 / 45$ to 9/4/45). 


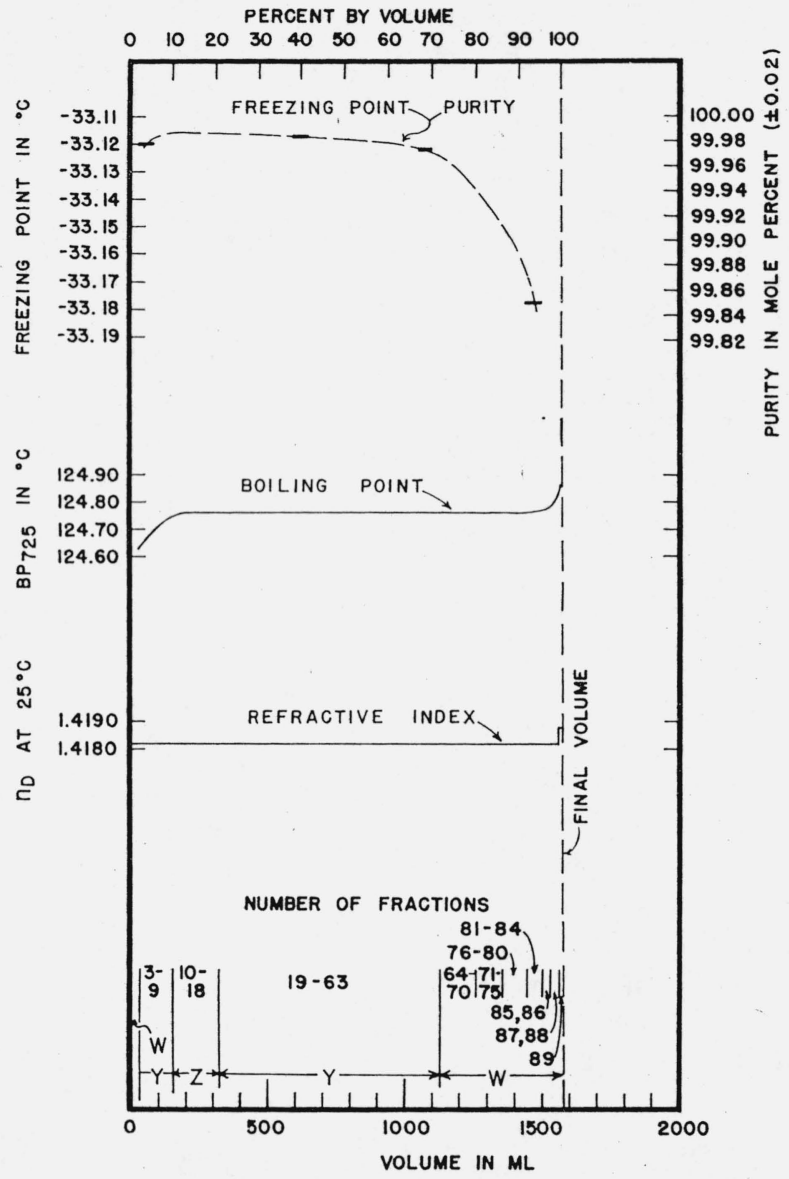

Figure 14.-Results of the second and final distillation of 3,3-diethylpentane.

A zeotropic distillation with ethylene glycol monoethyl ether at $725 \mathrm{~mm} \mathrm{Hg}$ in still $13(11 / 17 / 45$ to $12 / 4 / 45)$. 


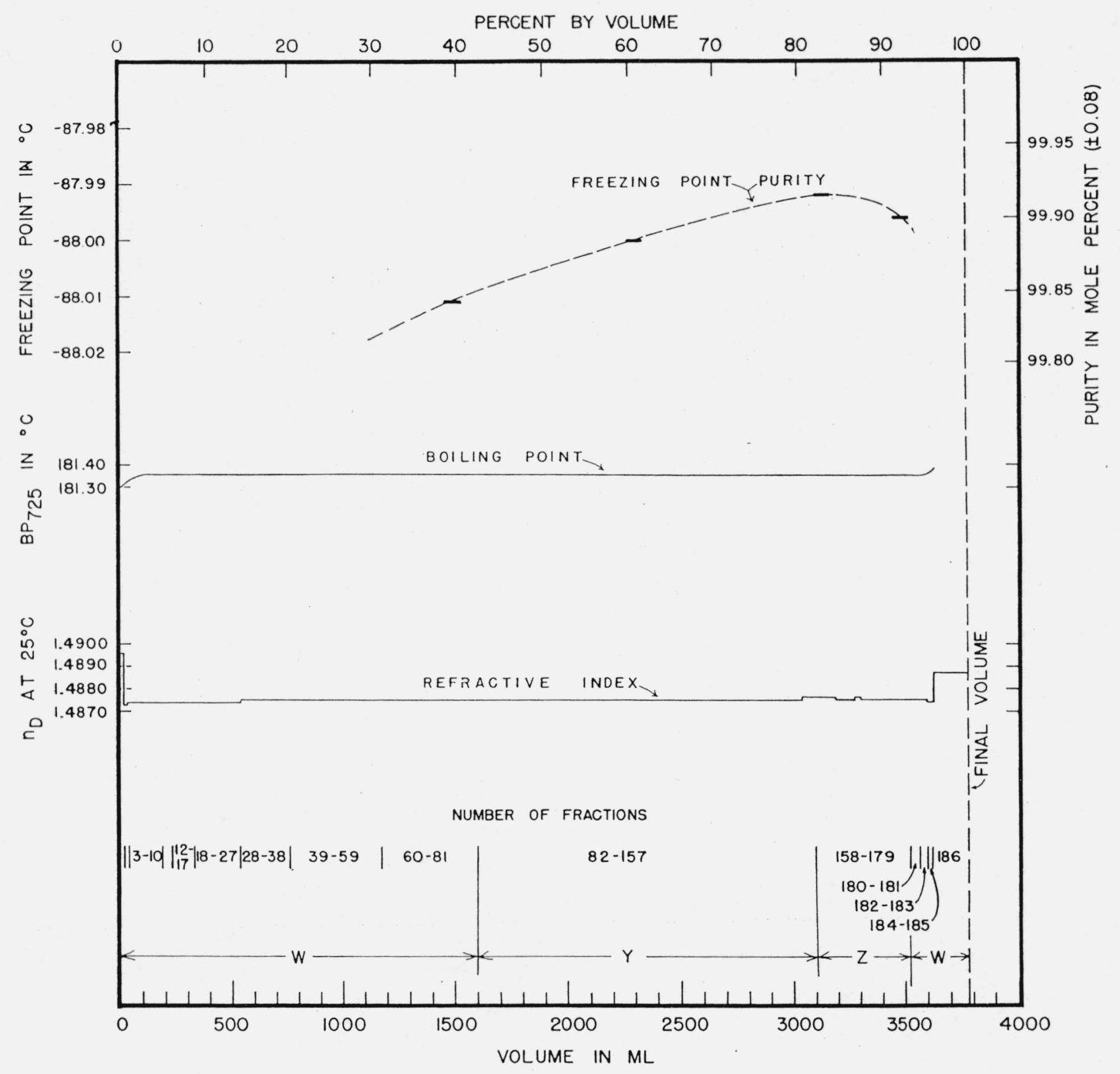

FigURE 15.-Results of the first and only distillation of n-butylbenzene.

Regular distillation at $725 \mathrm{~mm} \mathrm{Hg}$ in still 9 (7/17/45 to 8/18/45). 


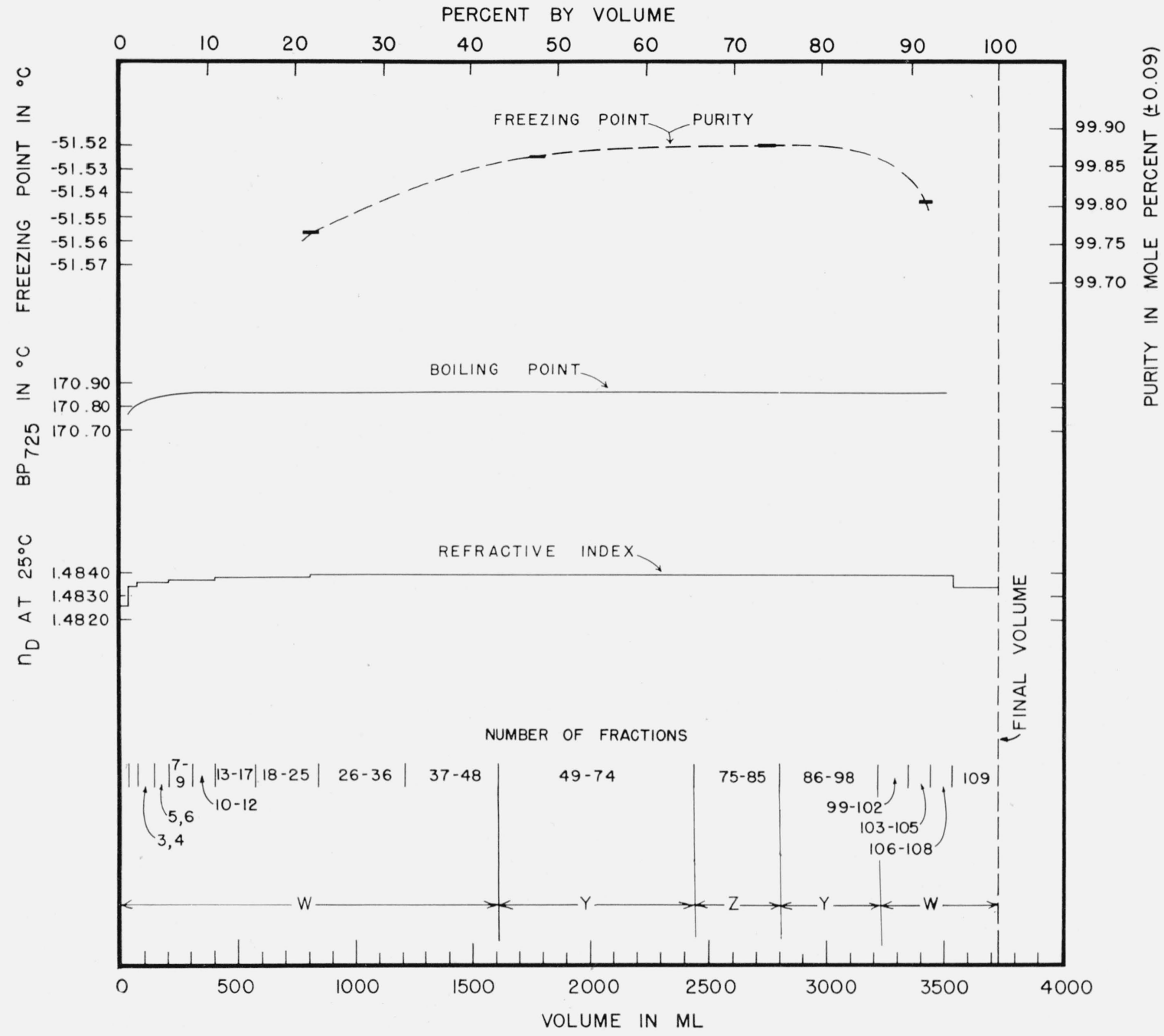

FIgURE 16.-Results of the first and only distillation of isobutylbenzene.

Regular distillation at $725 \mathrm{~mm} \mathrm{Hg}$ in still 8 (8/27/45 to 9/16/45). 


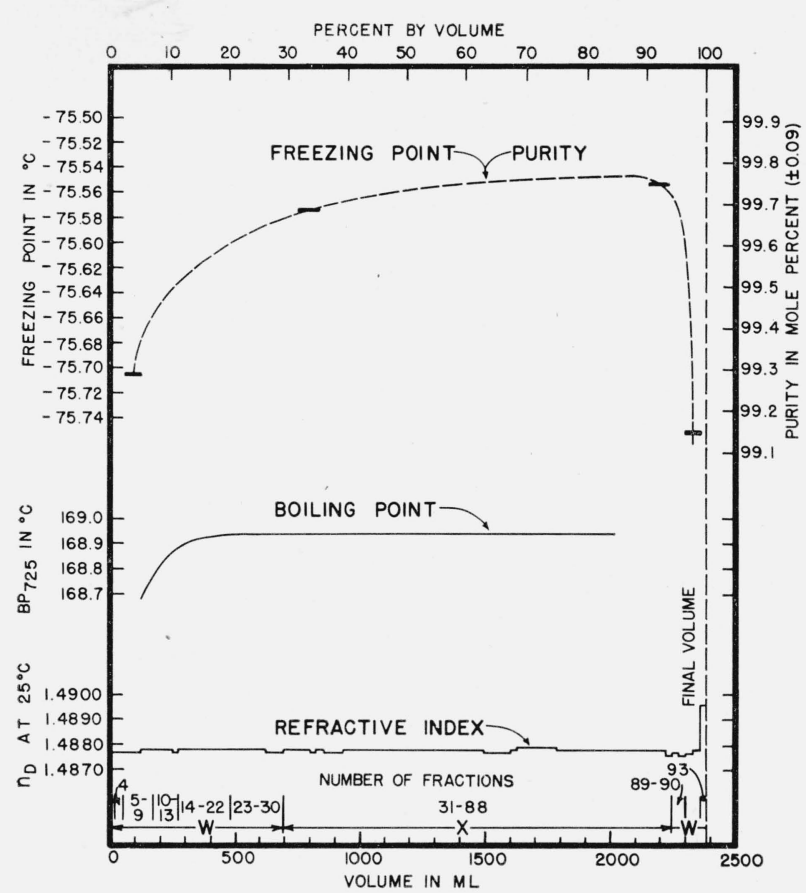

FIGURE 17.-Results of the first distillation of sec-butylbenzene.

Azeotropic distillation with diethylene glycol monomethyl ether at $725 \mathrm{~mm}$. $\mathrm{Hg}$ in still 8 (10/2/44 to 10/19/44).

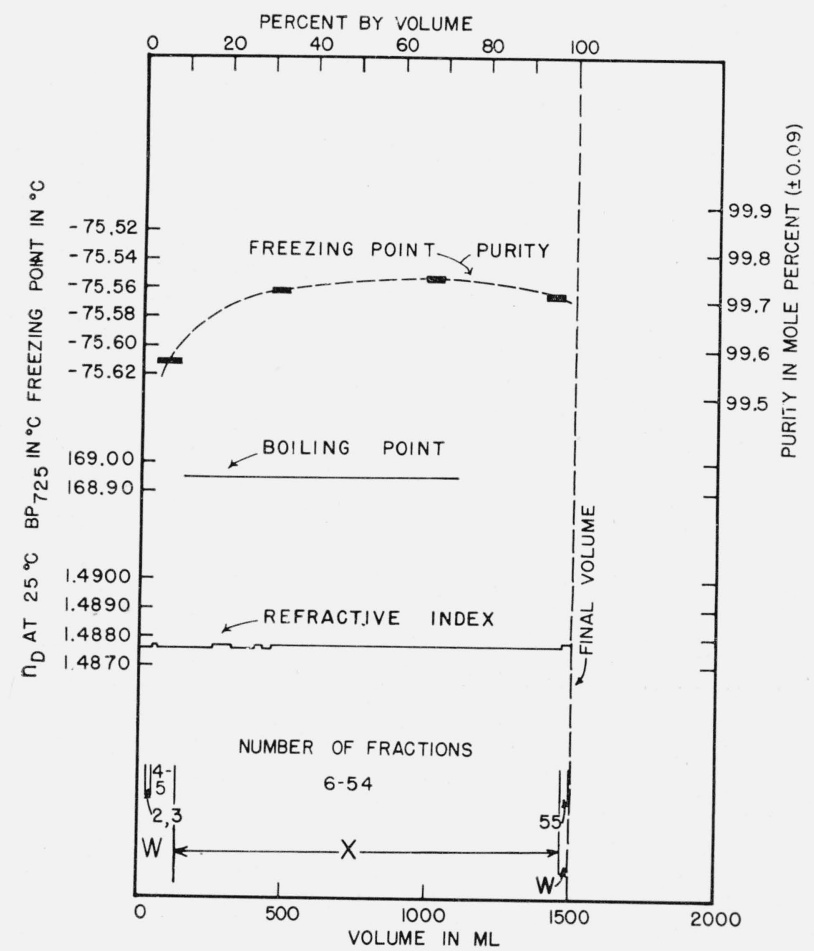

FIGURE 18.-Results of the second distillation of sec-butylbenzene.

Azeotropic distillation with diethylene glycol monomethyl ether at $725 \mathrm{~mm}$ Hg in still $13(6 / 29 / 45$ to $7 / 12 / 45)$.

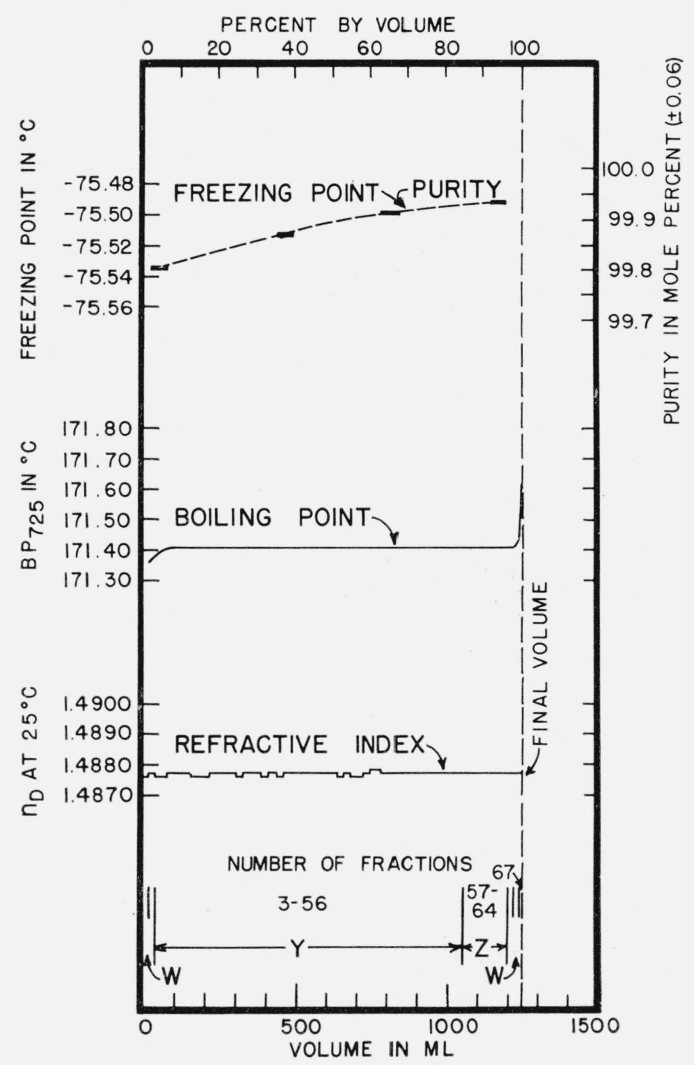

FIGURE 19.--Results of the third and final distillation of secbutylbenzene.

Regular distillation at $725 \mathrm{~mm} \mathrm{Hg}$ in still $12(8 / 17 / 45$ to $9 / 4 / 45)$. 


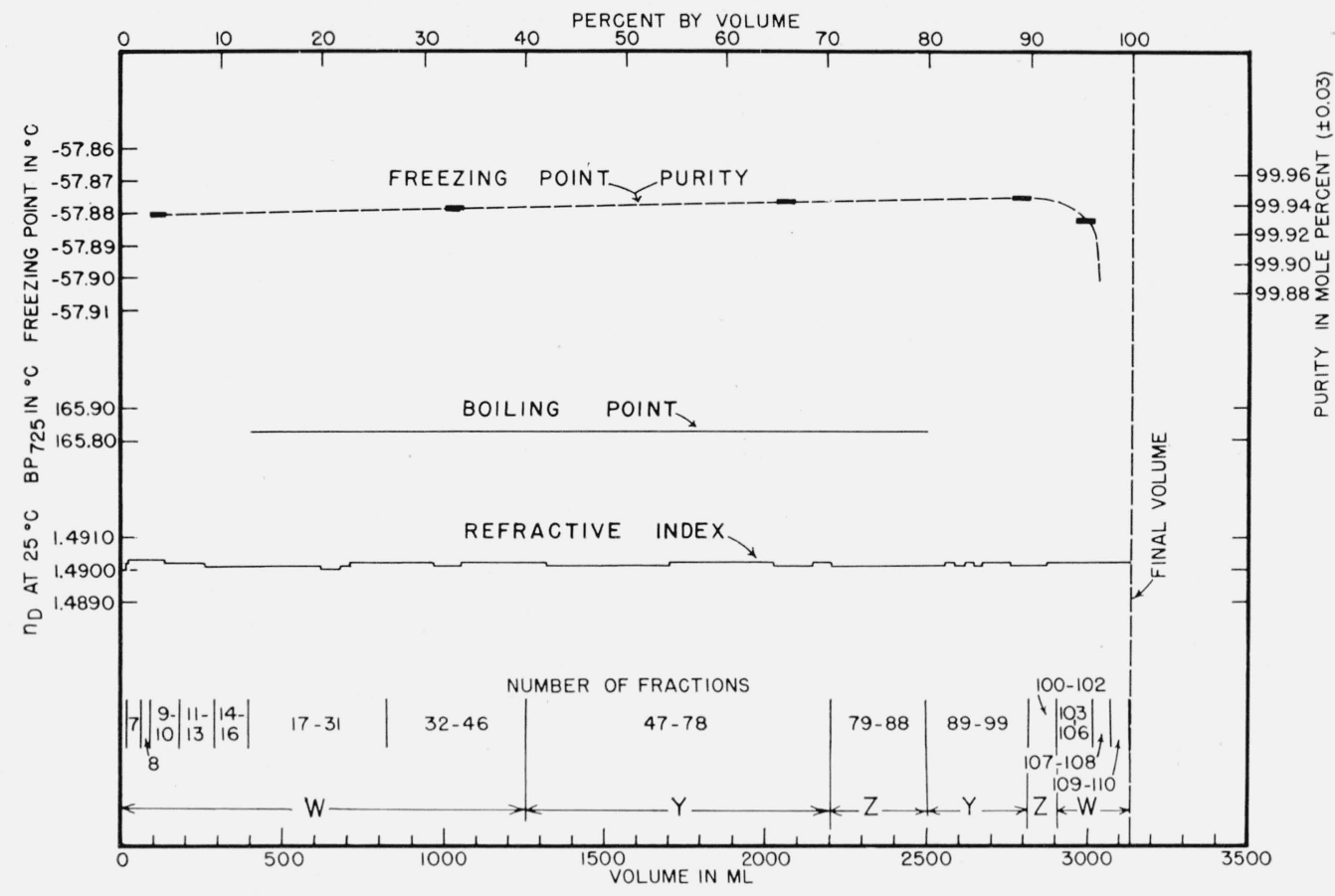

FIGURE 20.-Results of the first and only distillation of tert-butylbenzene.

Azeotropic distillation with diethylene glycol monomethyl ether at $725 \mathrm{~mm} \mathrm{Hg}$ in still 8 (10/19/44 to 11/9/44).

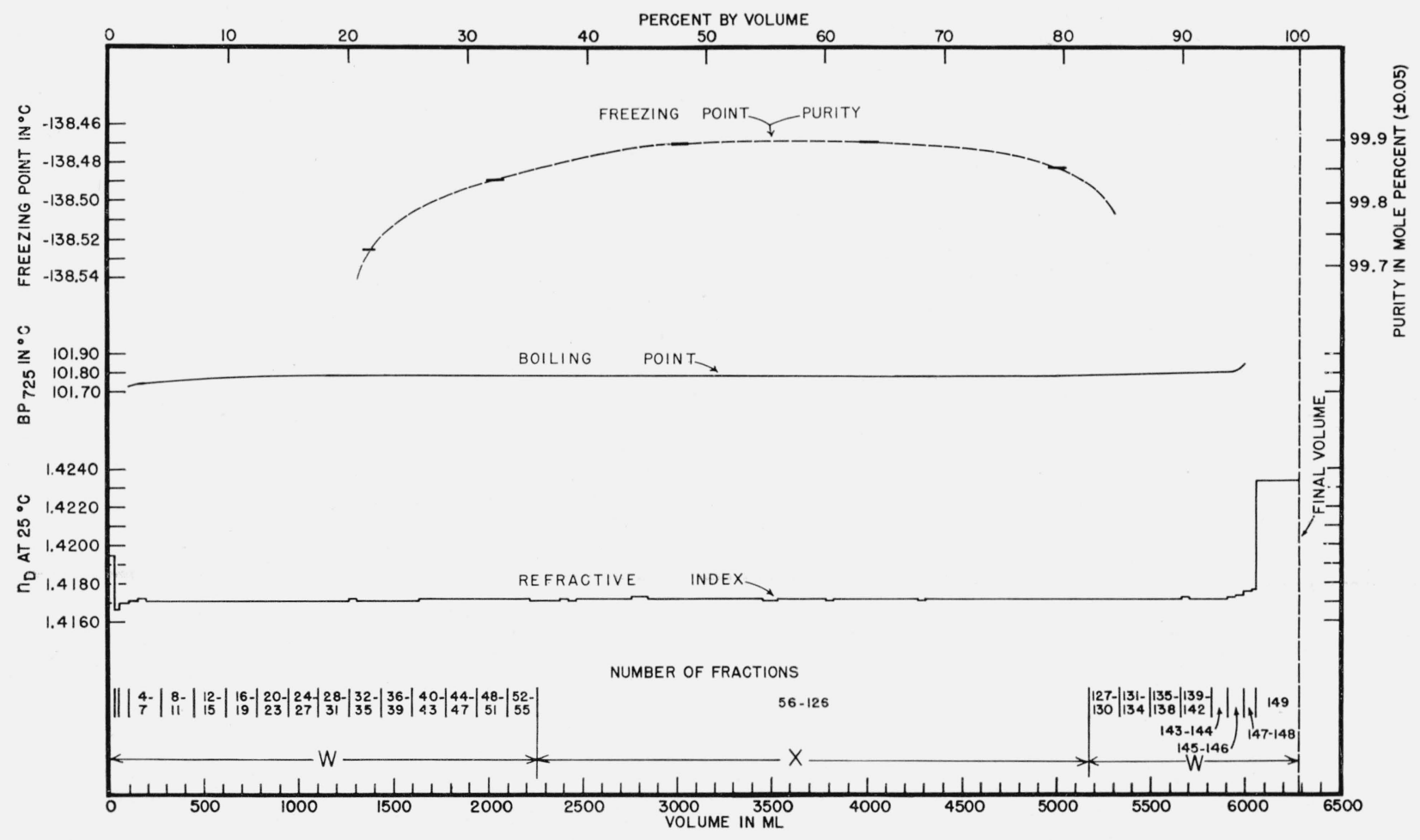

Figure 21.-Results of the first distillation of ethylcyclopentane.

Regular distillation at $725 \mathrm{~mm} \mathrm{Hg}$ in still 15 (9/20/44 to 10/10/44 . 


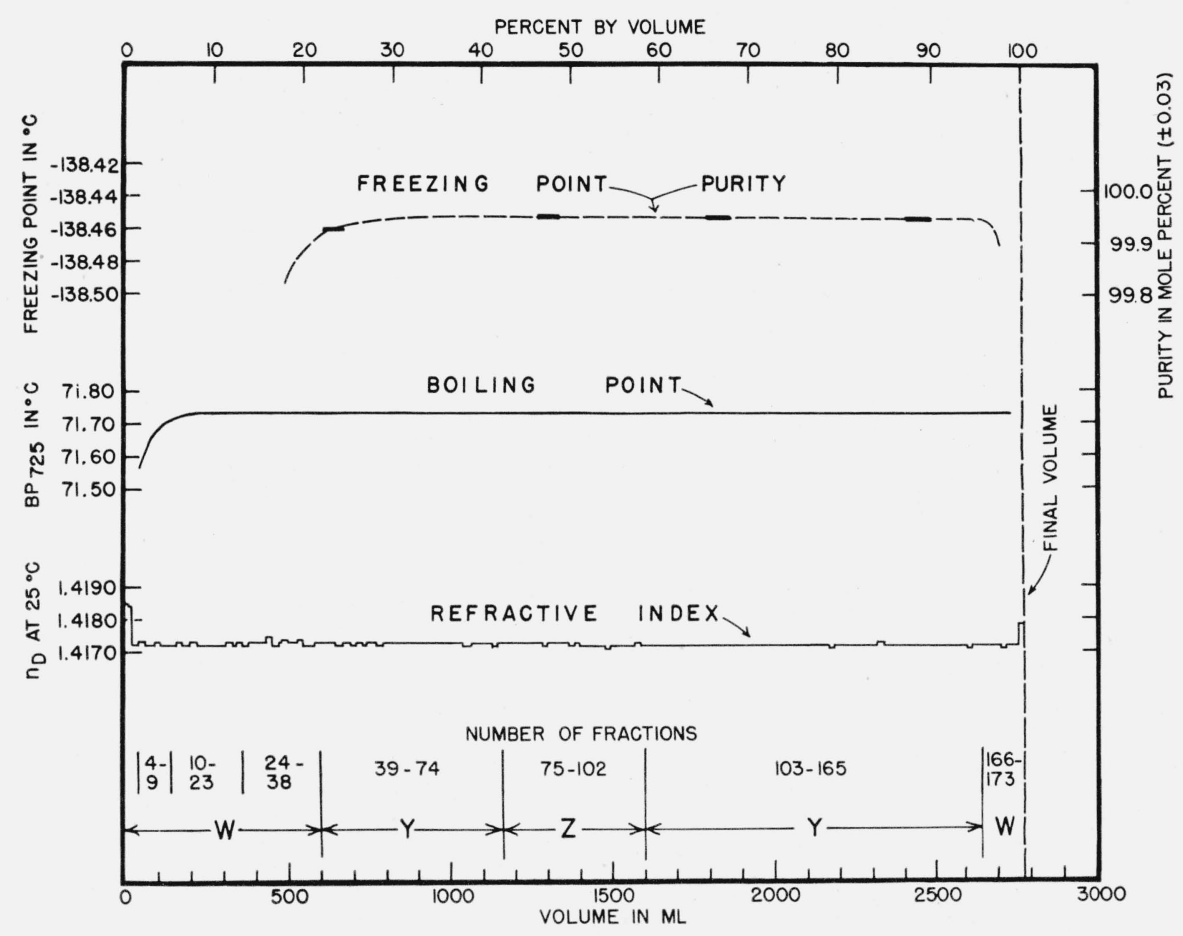

FIGURE 22.--Results of the second and final distillation of ethylcyclopentane. Azeotropic distillation with ethanol at $725 \mathrm{~mm} \mathrm{Hg}$ in still 13 (3/7/45 to 4/5/45), 


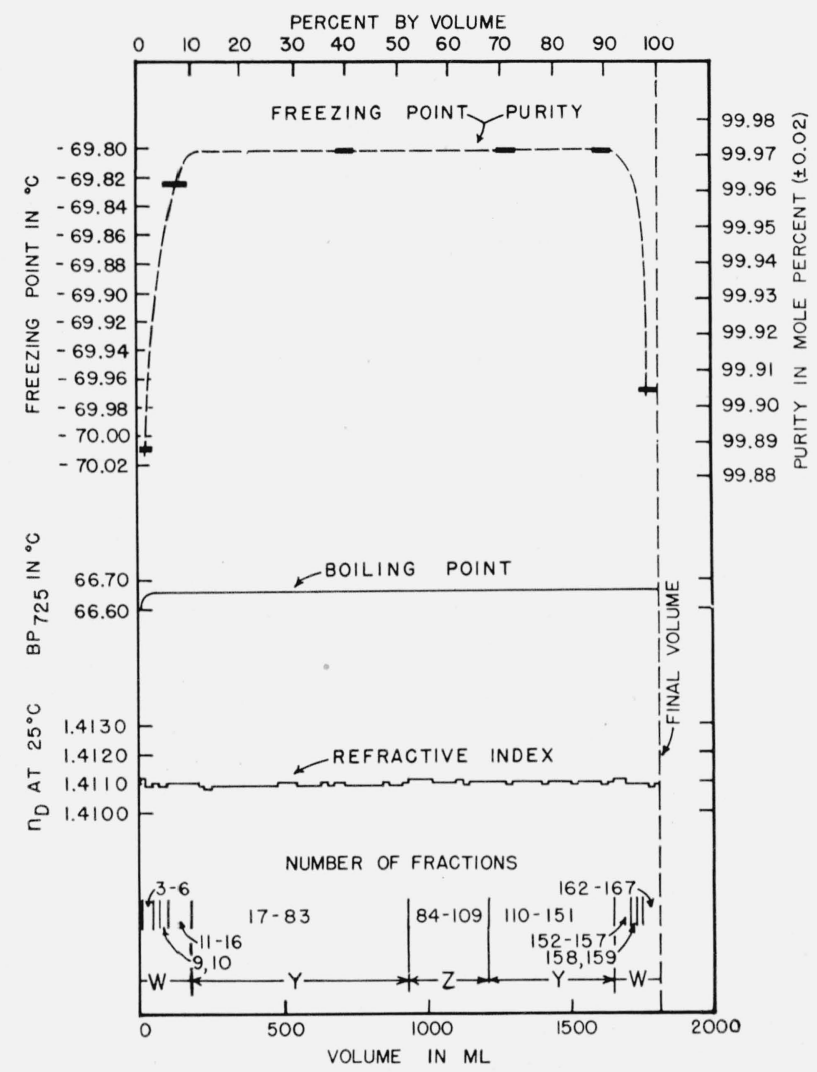

FIGURE 23.-Results of the first and only distillation of 1,1dimethylcyclopentane.

Azeotropic distillation with ethanol at $725 \mathrm{~mm} \mathrm{Hg}$ in still 9 (8/27/45 to 9/28/45).

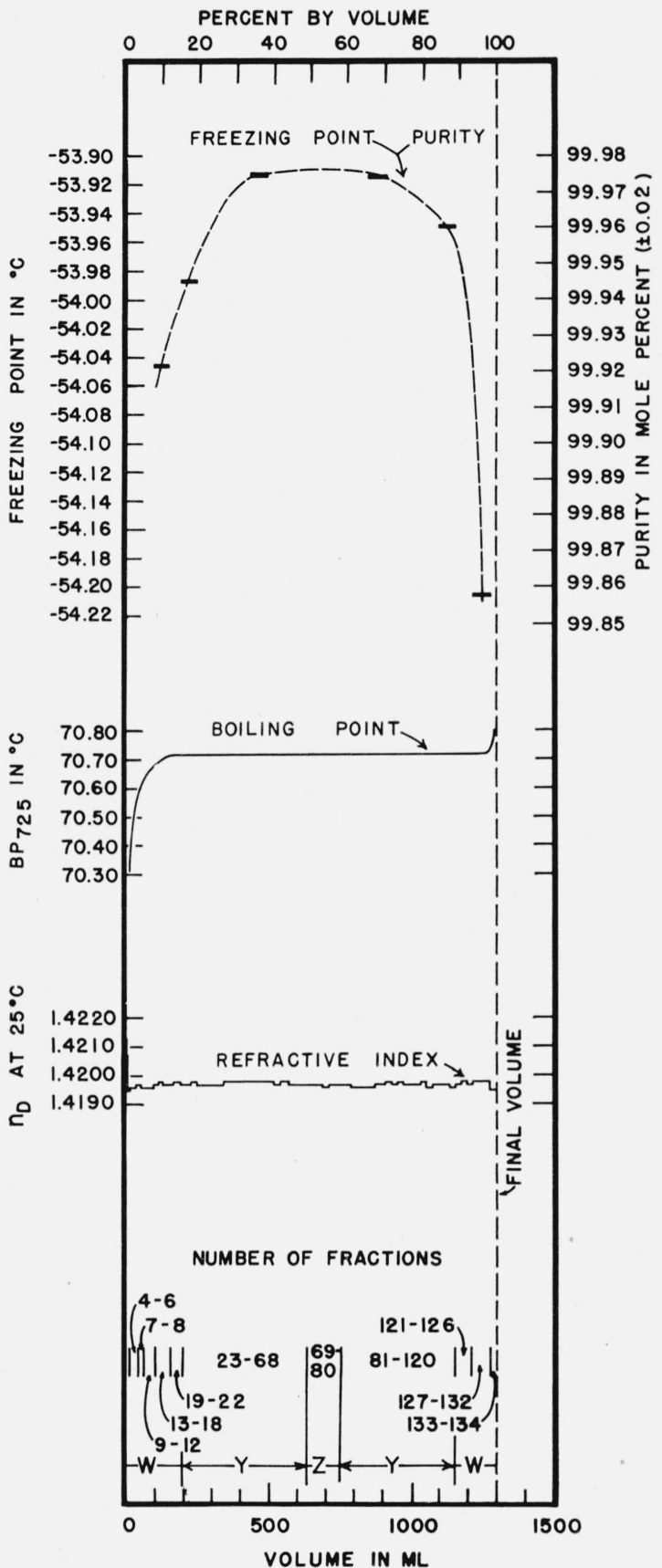

Figure 24.-Results of the first and only distillation of cis1,2-dimethylcyclopentane.

Azeotropic distillation with ethanol at $725 \mathrm{~mm} \mathrm{Hg}$ in still $9(9 / 29 / 45$ to $10 / 24 / 45)$. 


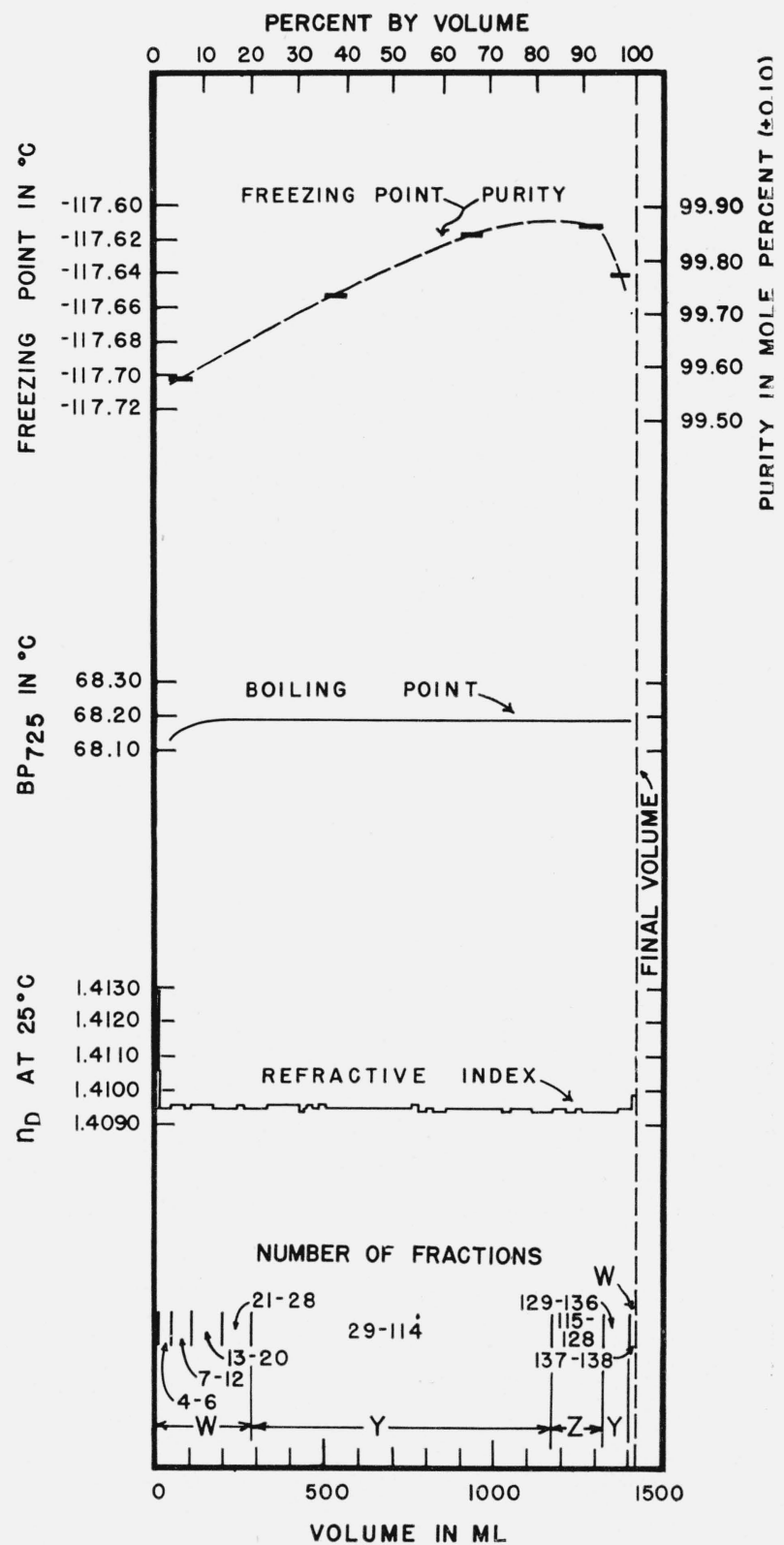

FIGURE 25.-Results of the first and only distillation of trans1,2-dimethylcyclopentane.

Azeotropic distillation with ethanol at $725 \mathrm{~mm} \mathrm{Hg}$ in still $4(10 / 2 / 45$ to $10 / 28 / 45)$. 


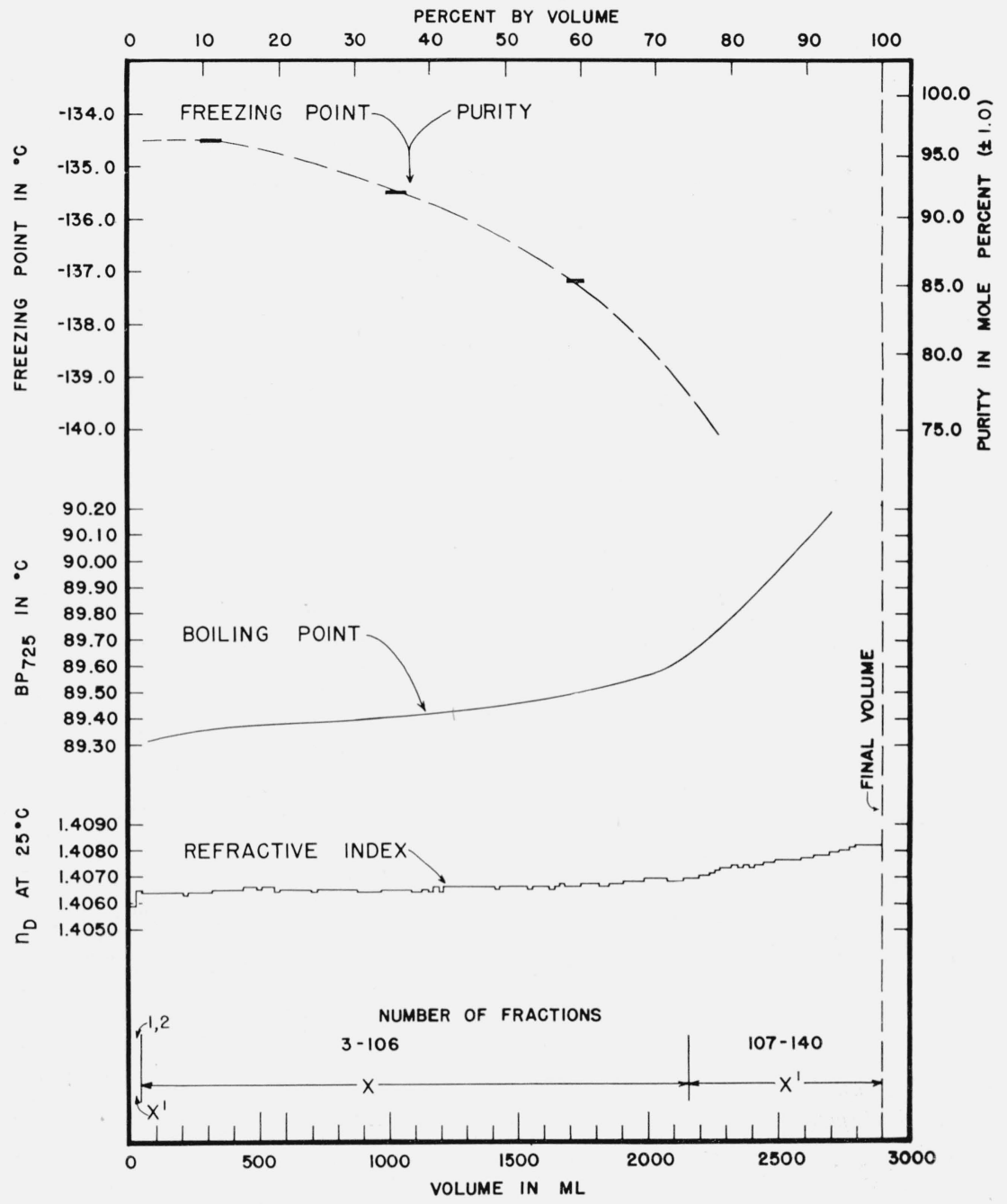

FIGURE 26.-Results of the first distillation of trans-1,3-dimethylcyclopentane. Regular distillation at $725 \mathrm{~mm} \mathrm{Hg}$ in still $4(11 / 6 / 44$ to $12 / 1 / 44)$.

Fractions 1, 2, and 107 to 140 (marked " $\mathrm{X}^{\prime \prime}$ ") were retained for further processing by the A PI Research Project 6. 


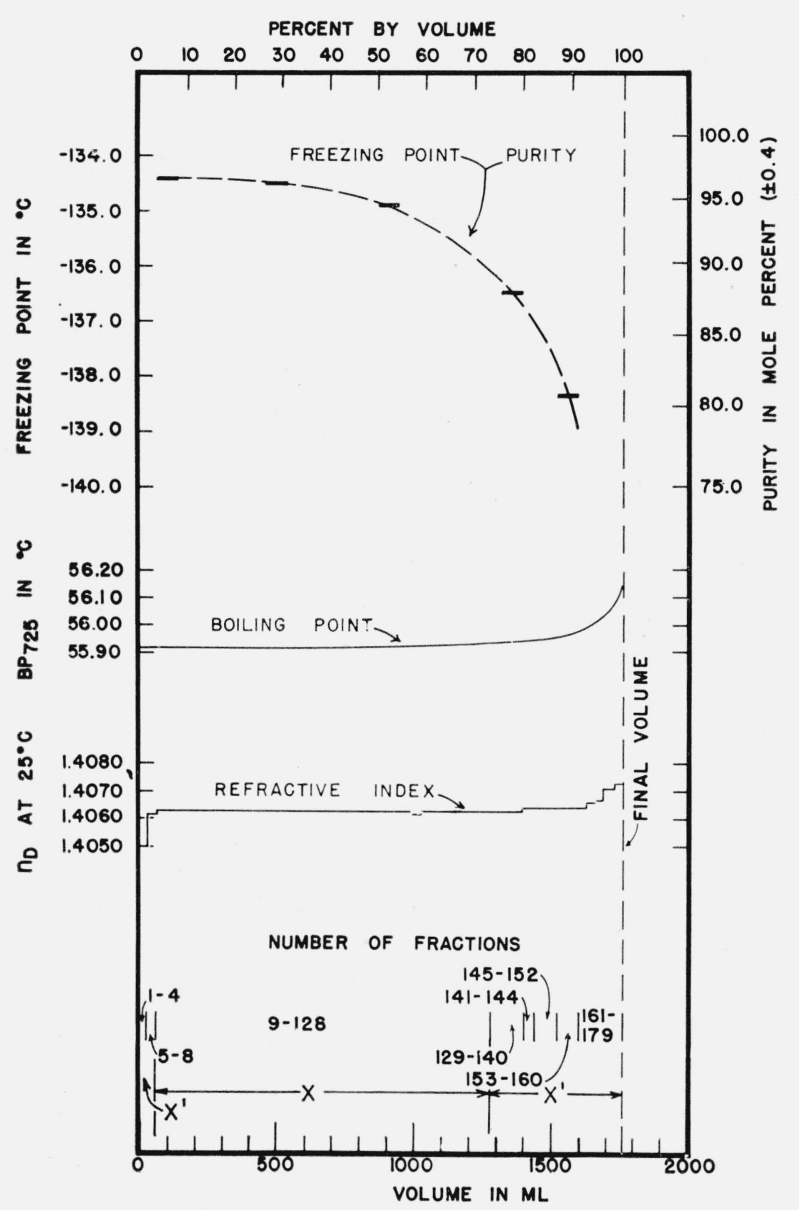

FIgure 27.-Results of the second distillation of trans-1,3dimethylcyclopentane.

Azeotropic distillation with methanol at $725 \mathrm{~mm} \mathrm{Hg}$ in still $10(5 / 26 / 45$ to $7 / 4 / 45)$.

Fractions 1 to 8 and 153 to 179 (marked " $\mathrm{X}^{\prime \prime \prime) ~ w e r e ~ r e t a i n e d ~ f o r ~ f u r t h e r ~}$ processing by the API Research Project 6 .

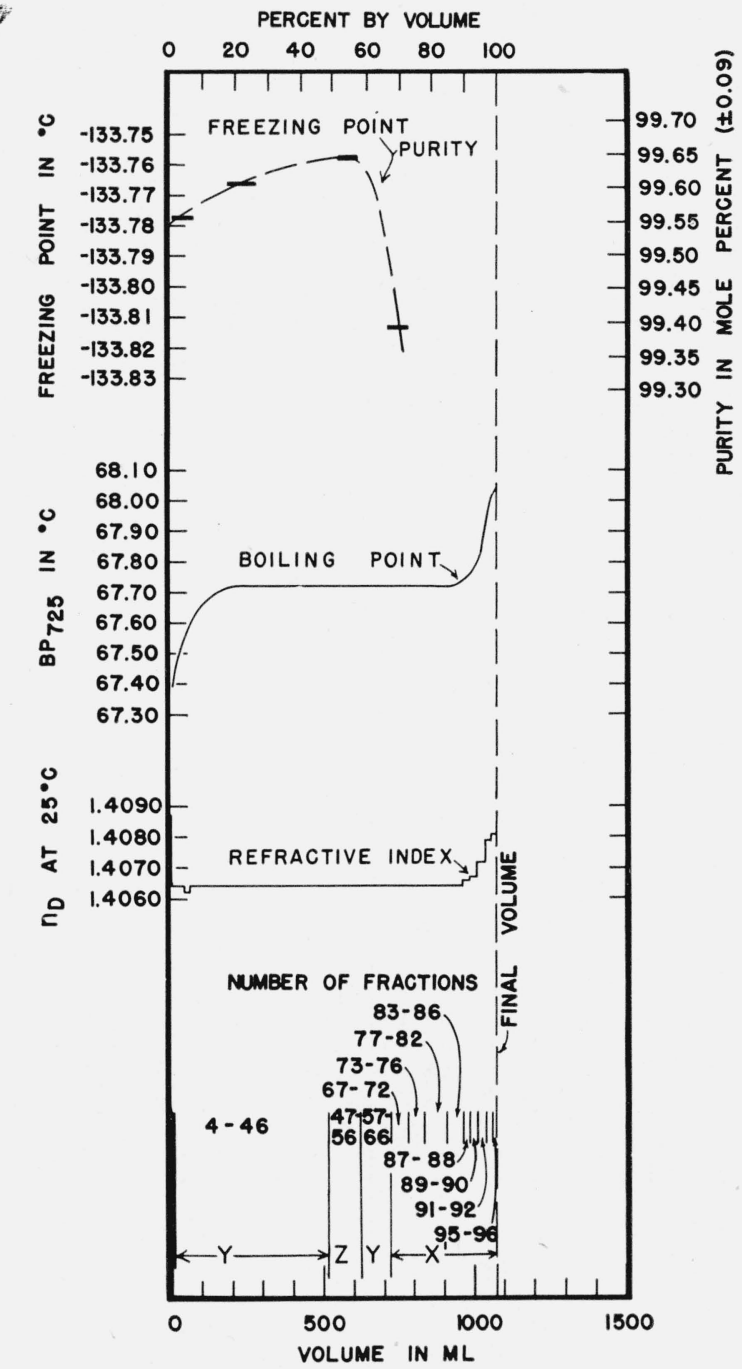

FIGURE 28.-Results of the third and final distillation of trans-1,3-dimethylcyclopentane.

Azeotropic distillation with ethanol at $725 \mathrm{~mm} \mathrm{Hg}$ in still $4(10 / 29 / 45$ to $11 / 20 / 45)$

Fractions 67 to 96 (marked " $\mathrm{X}$ ") ) were retained for further processing by the API Research Project 6. 


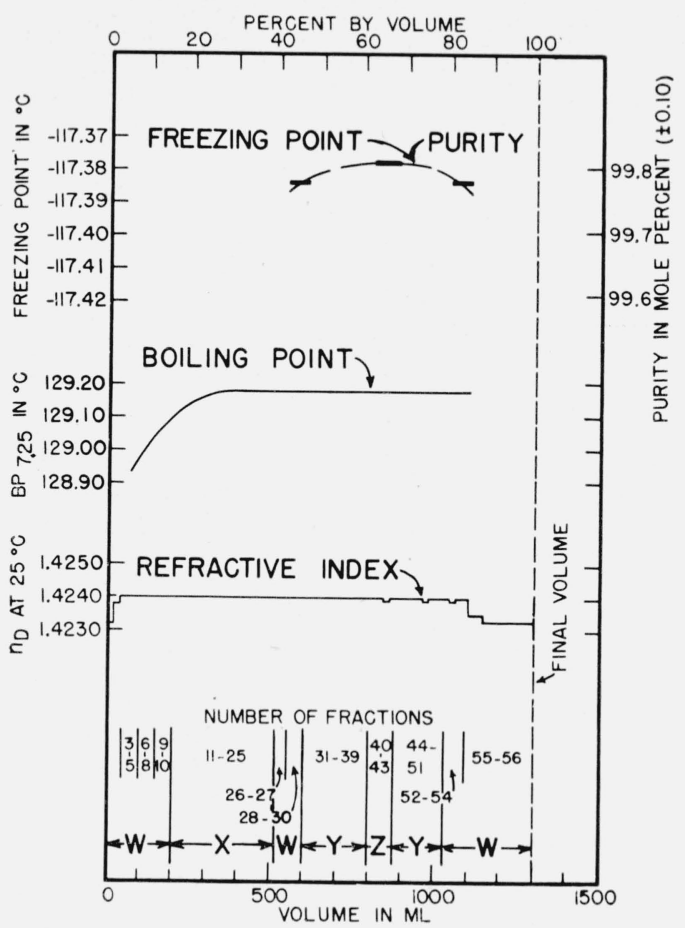

FIGURE 29.-Results of the first distillation of n-propylcyclopentane.

Regular distillation at $725 \mathrm{~mm} \mathrm{Hg}$ in still 4 (6/12/44 to 6/24/44).

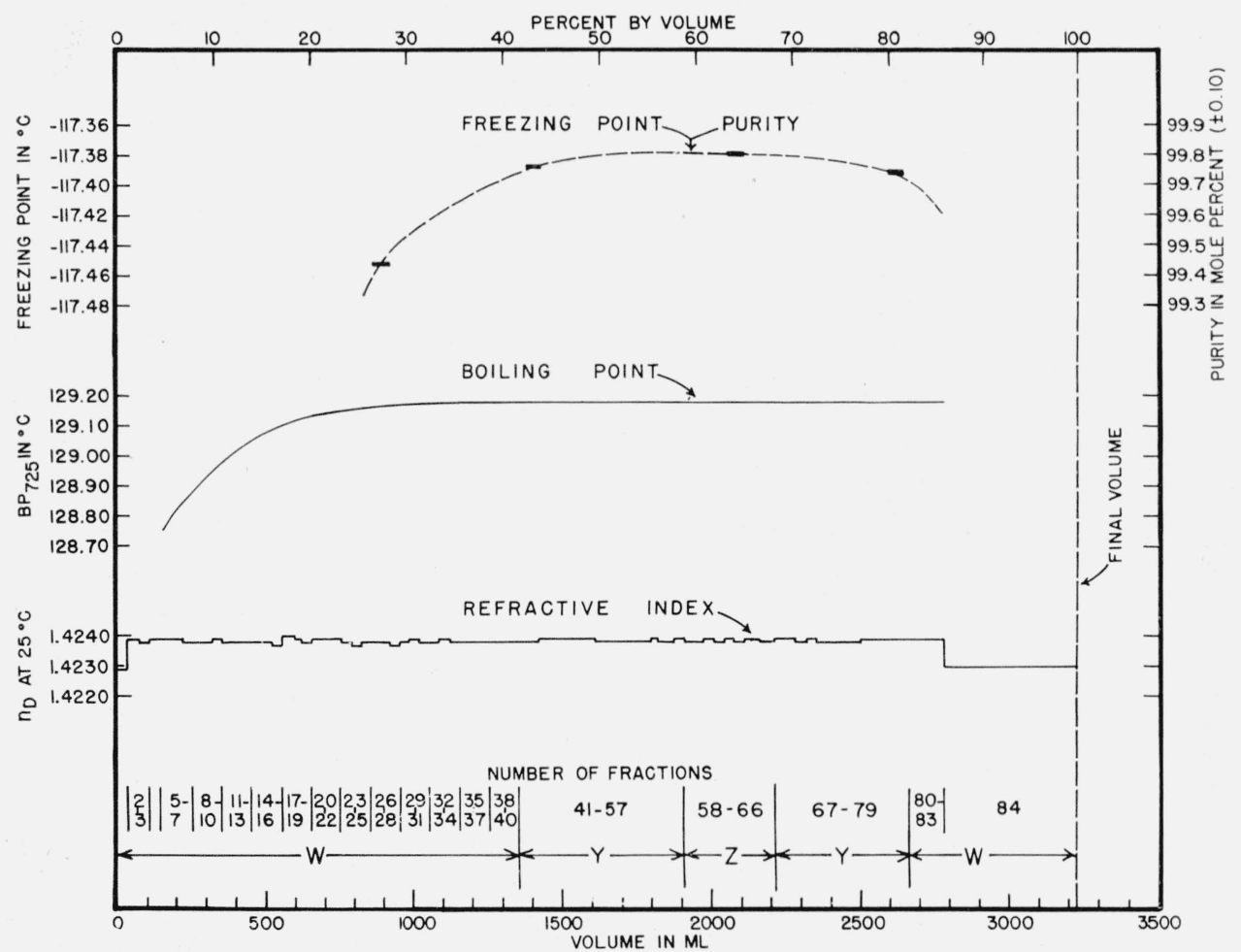

FIGURE 30.--Results of the second and final distillation of n-propylcyclopentane.

Regular distillation at $725 \mathrm{~mm} \mathrm{Hg}$ in still 13 (12/7/44 to 12/22/44).

See table 1 for the composition of the charge for this distillation.

\section{Purification and Purity of Hydrocarbons}




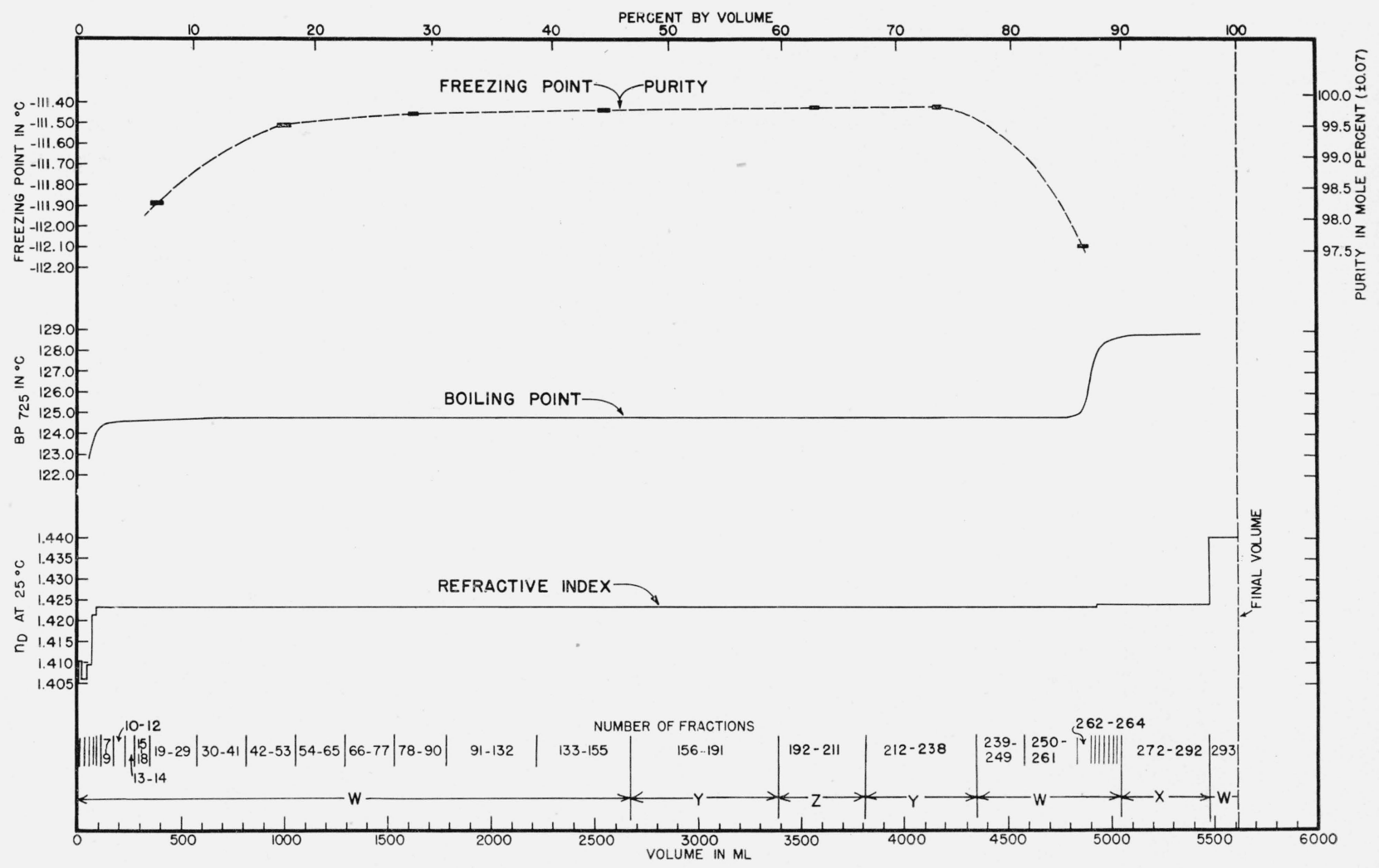

Figure 31.-Results of the first and only distillation of isopropylcyclopentane.

Regular distillation at $725 \mathrm{~mm} \mathrm{Hg}$ in still 10 (7/3/44 to 8/20/44.)

The portion marked ' $\mathrm{X}$ "' was used as part of a charge of $n$-propylcyclopentane (see fig. 30 and footnote $n$ of table 1). 


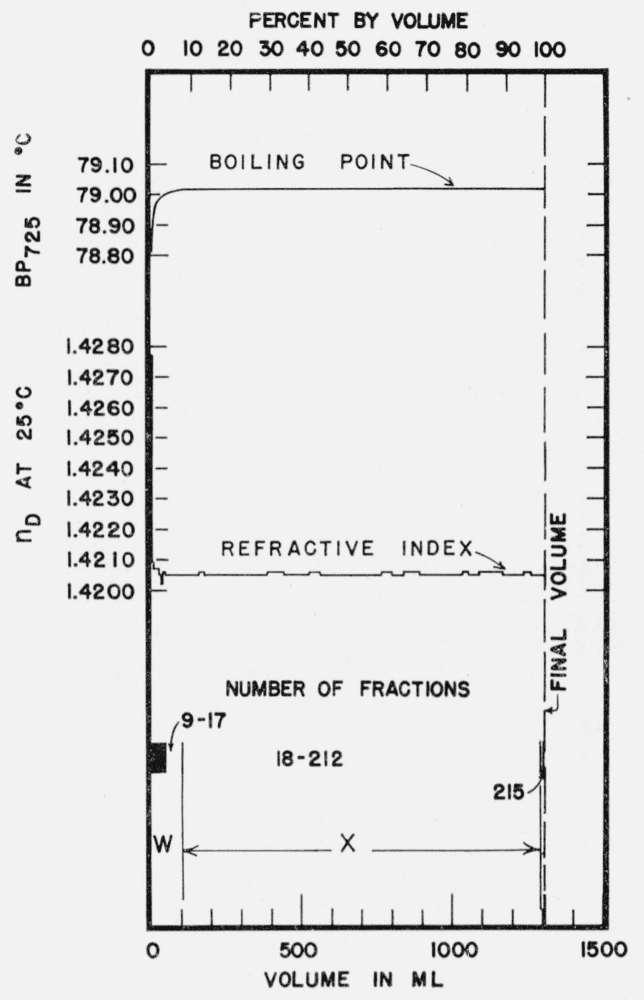

Figure 32.-Results of the first distillation of 1,1,2trimethylcyclopentane.

Azeotropic distillation with isopropanol at $725 \mathrm{~mm} \mathrm{Hg}$ in still 9 (11/23/45 to $1 / 7 / 46)$.

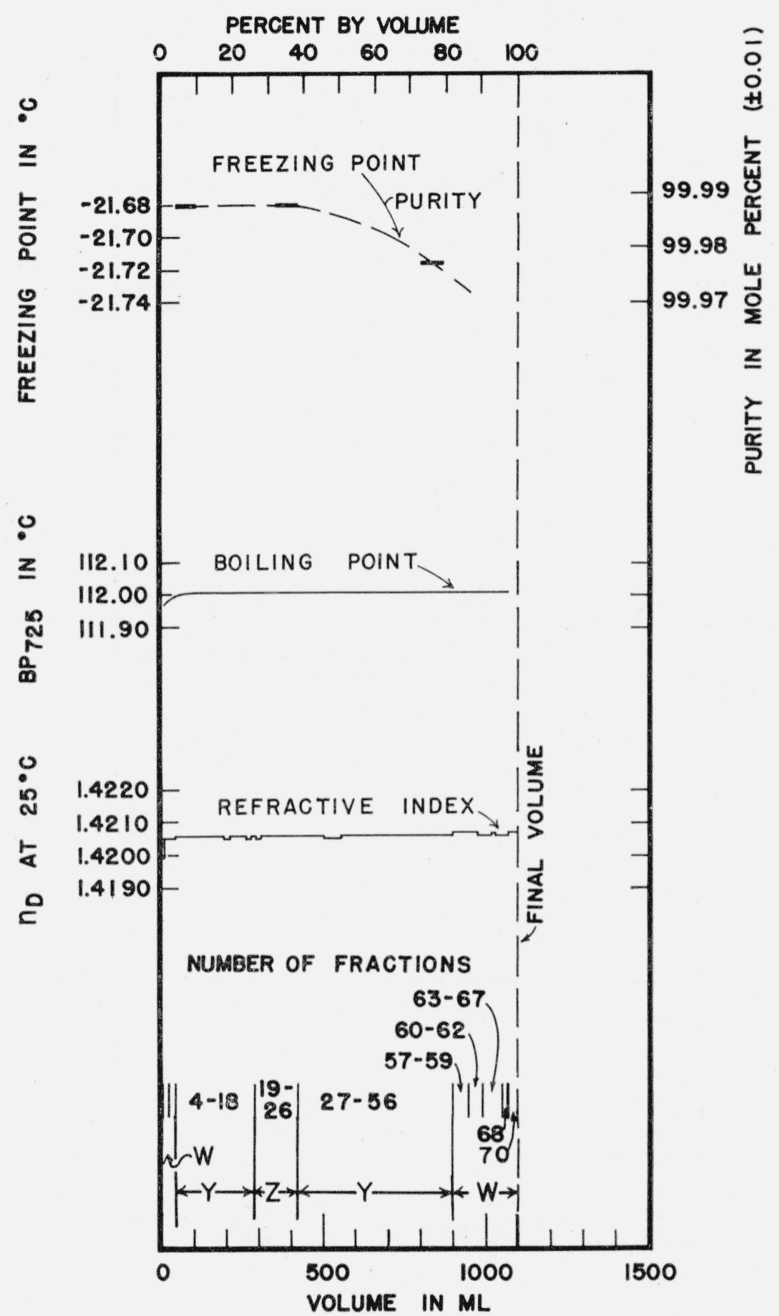

Figure 33.-Results of the second and final distillation of 1,1,2-trimethylcyclopentane.

Regular distillation at $725 \mathrm{~mm} \mathrm{Hg}$ in still $3(1 / 22 / 46$ to 2/16/46). 


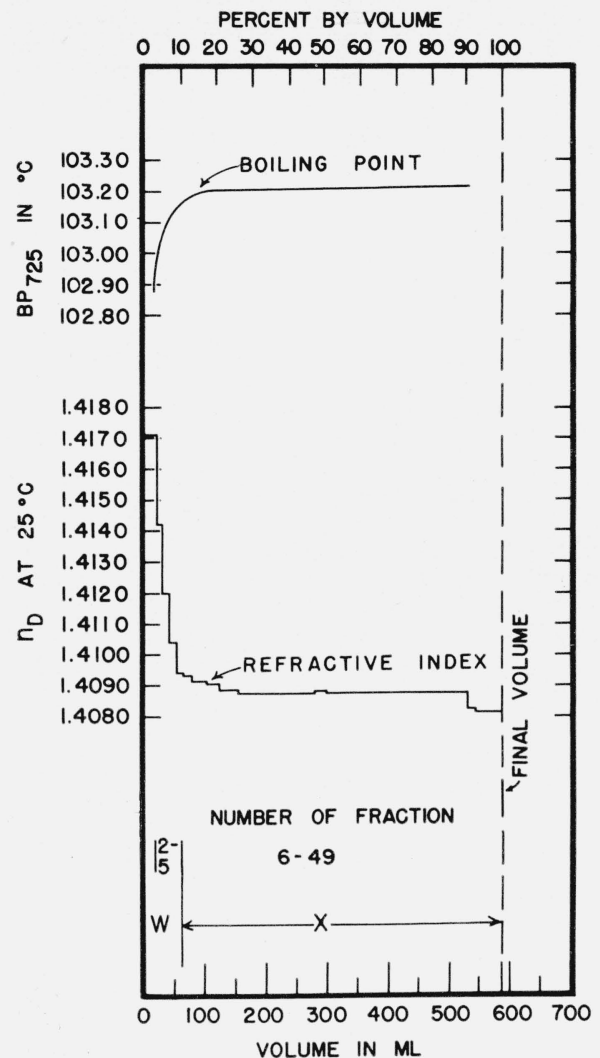

Figure 34.-Results of the first distillation of 1,1,3trimethylcyclopentane.

Regular distillation at $725 \mathrm{~mm} \mathrm{Hg}$ in still 3 (10/6/44 to 10/16/44).

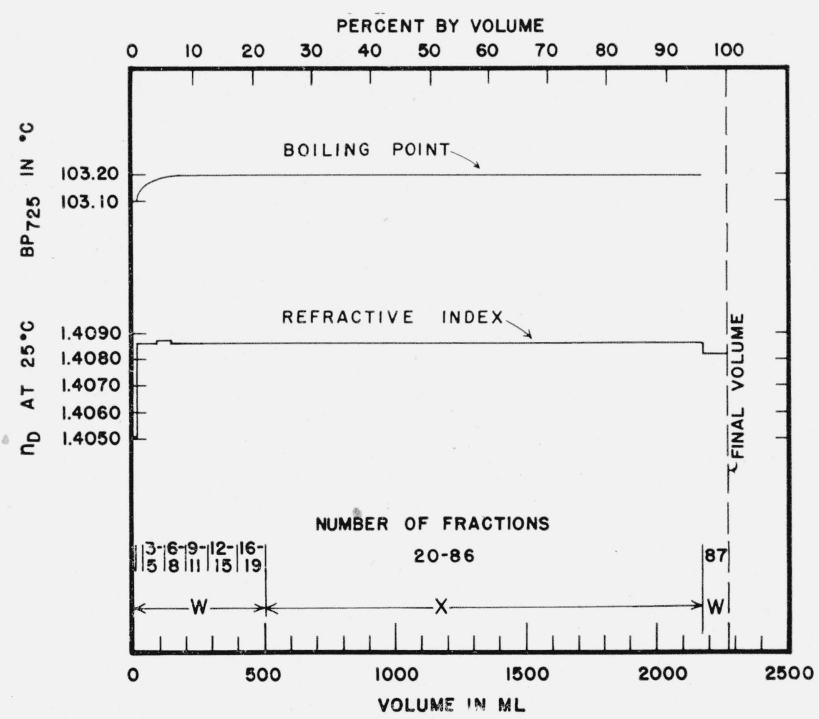

FIGURE 35.-Results of the second distillation of 1,1,3trimethylcyclopentane.

Regular distillation at $725 \mathrm{~mm} \mathrm{Hg}$ in still $12(3 / 13 / 45$ to $4 / 5 / 45)$. See table 1 for the composition of the charge for this distillation.

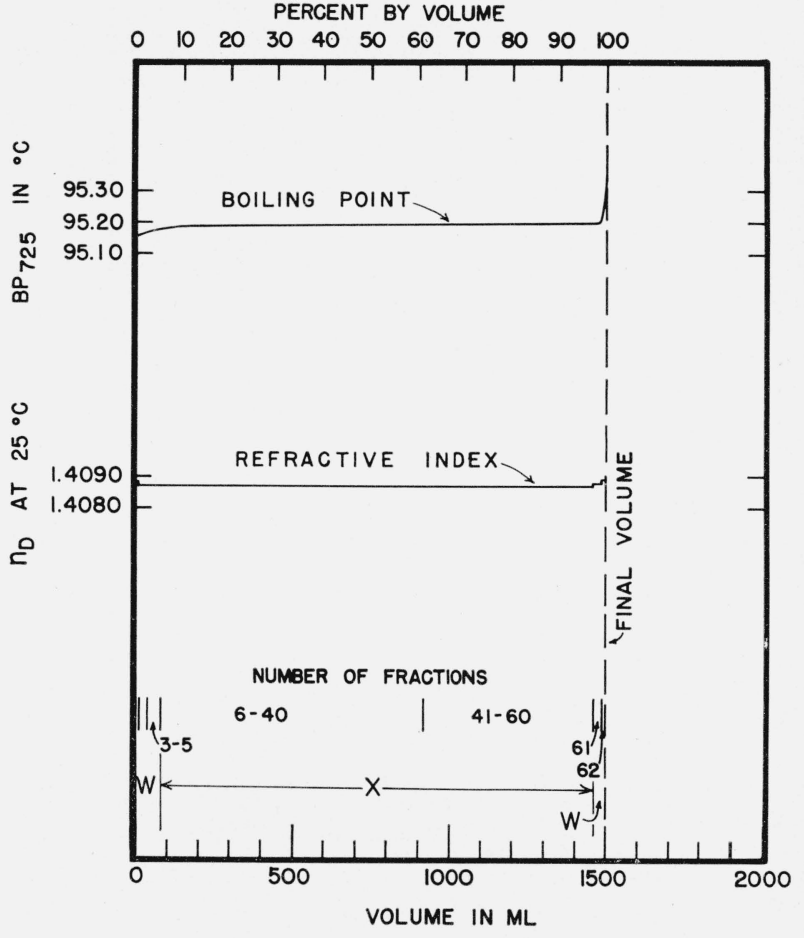

Figure 36.-Results of the third distillation of 1,1,3trimethylcyclopentane.

Azeotropic distillation with ethylene glycol monomethyl ether at $725 \mathrm{~mm}$ $\mathrm{Hg}$ in still $12(10 / 1 / 45$ to $10 / 25 / 45)$. 


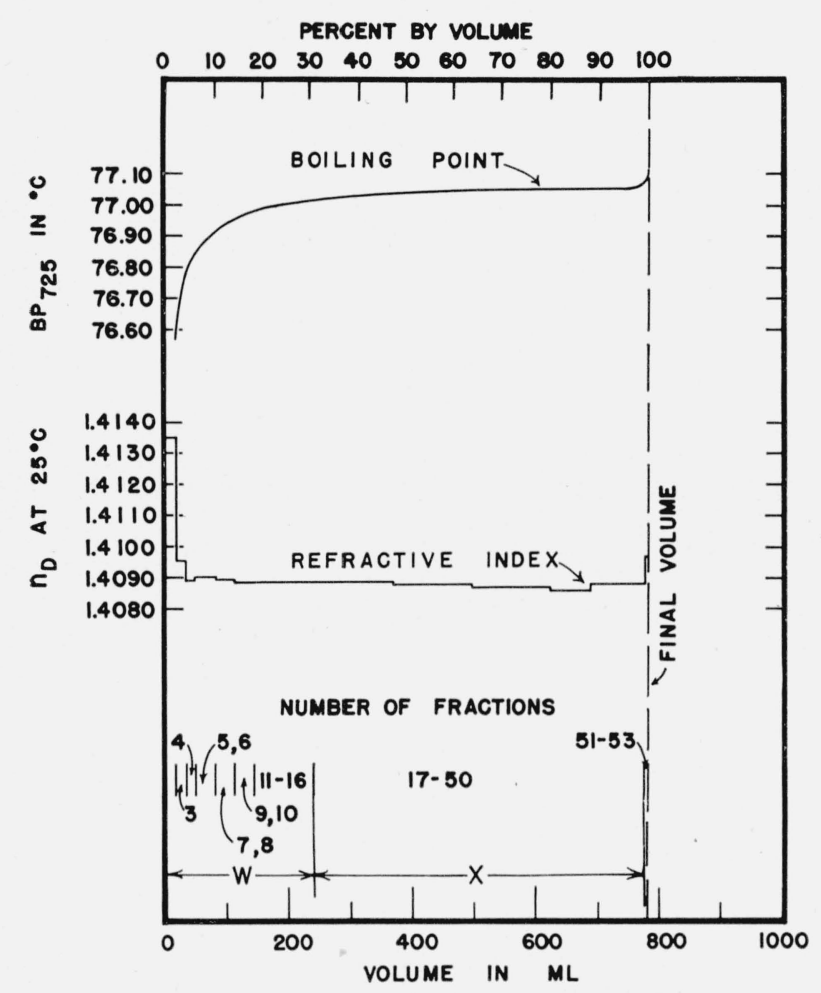

FIGURE 37.-Results of the fourth distillation of 1,1,3trimethylcyclopentane.

Azeotropic distillation with isopropanol at $725 \mathrm{~mm} \mathrm{Hg}$ in still 7 (11/17/45 to $11 / 27 / 45)$.

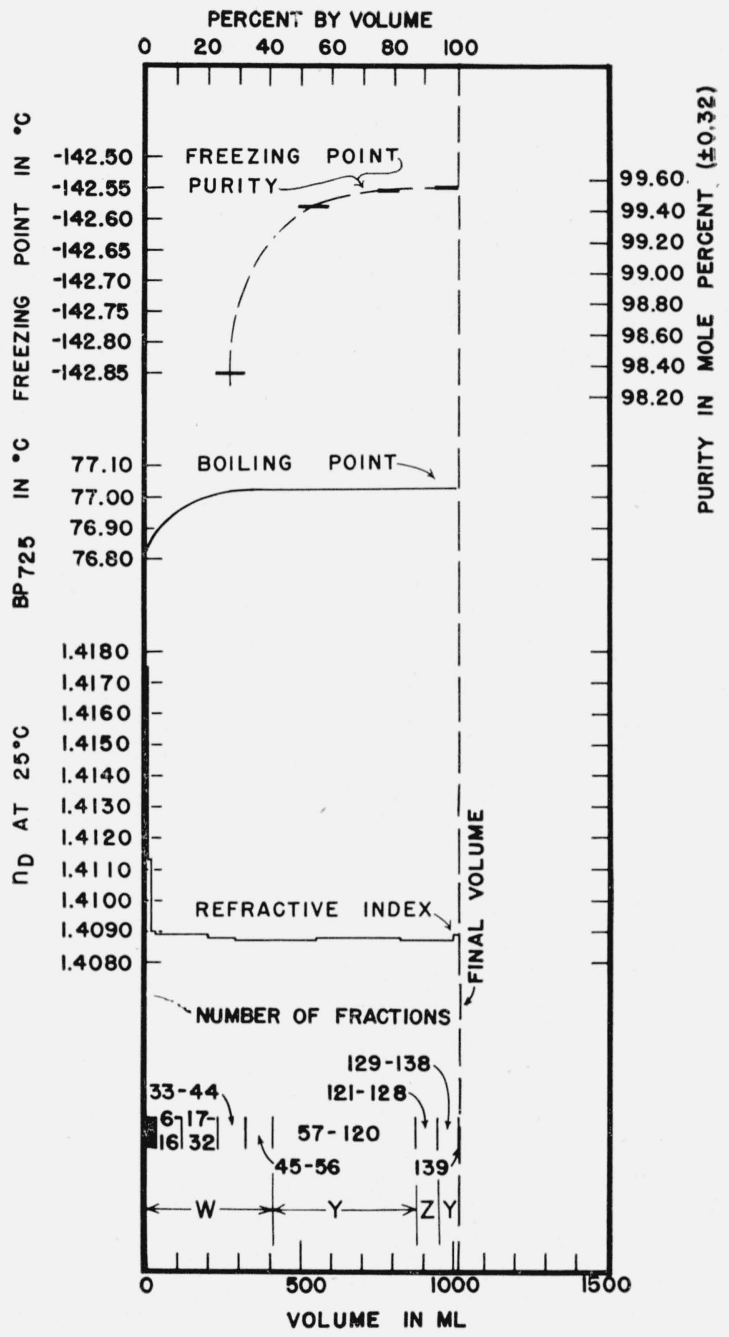

Figure 38.-Results of the fifth and final distillation of 1,1,3-trimethylcyclopentane.

Azeotropic distillation with isopropanol at $725 \mathrm{~mm} \mathrm{Hg}$ in still $4(1 / 3 / 46$ to $1 / 29 / 46)$

See table 1 for composition of the charge for this distillation. 


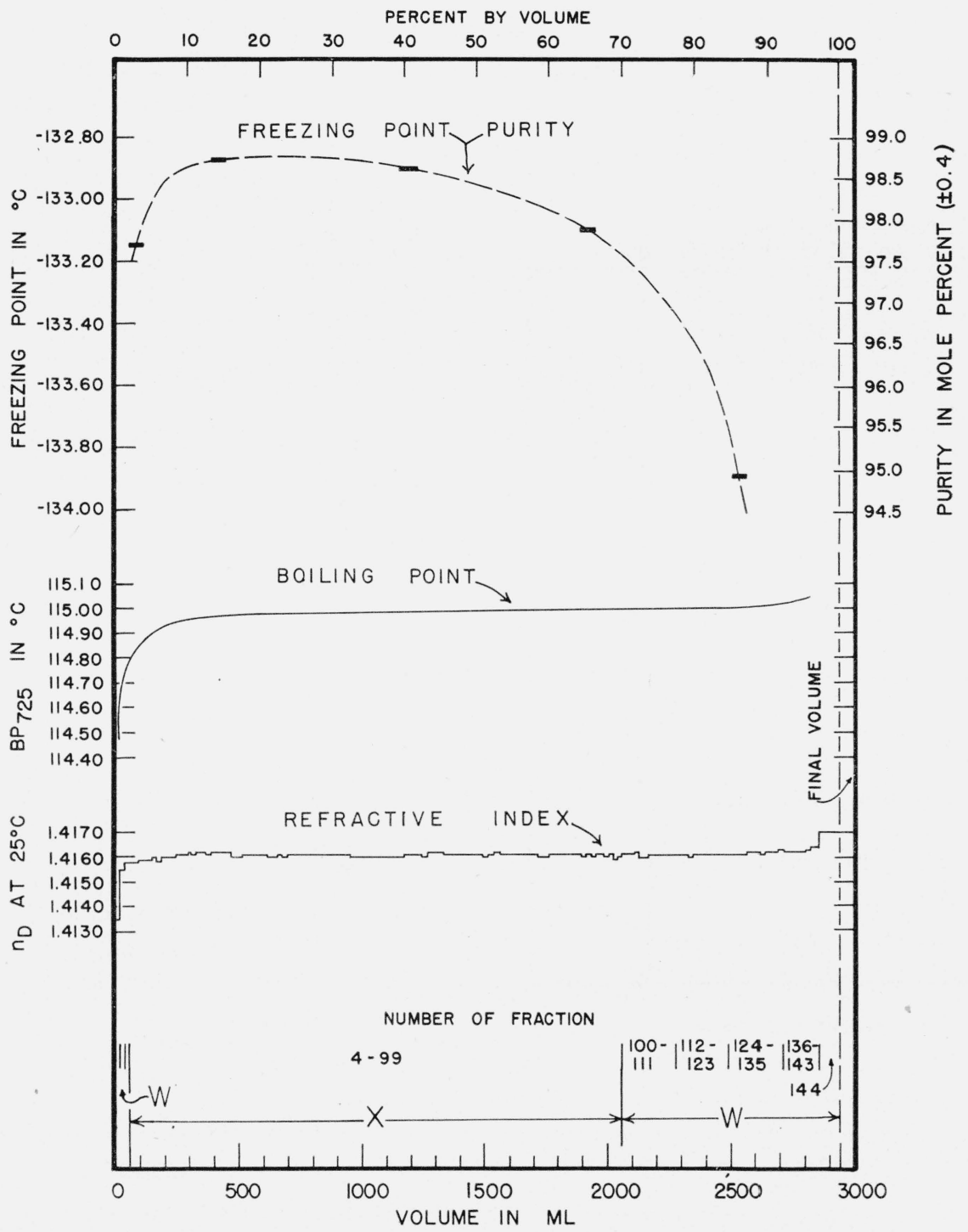

Figure 39.-Results of the first distillation of cis, cis, trans-1,2,4-trimethylcyclopentane. Regular distillation at $725 \mathrm{~mm} \mathrm{Hg}$ in still $4(12 / 5 / 44$ to $1 / 5 / 45)$. 


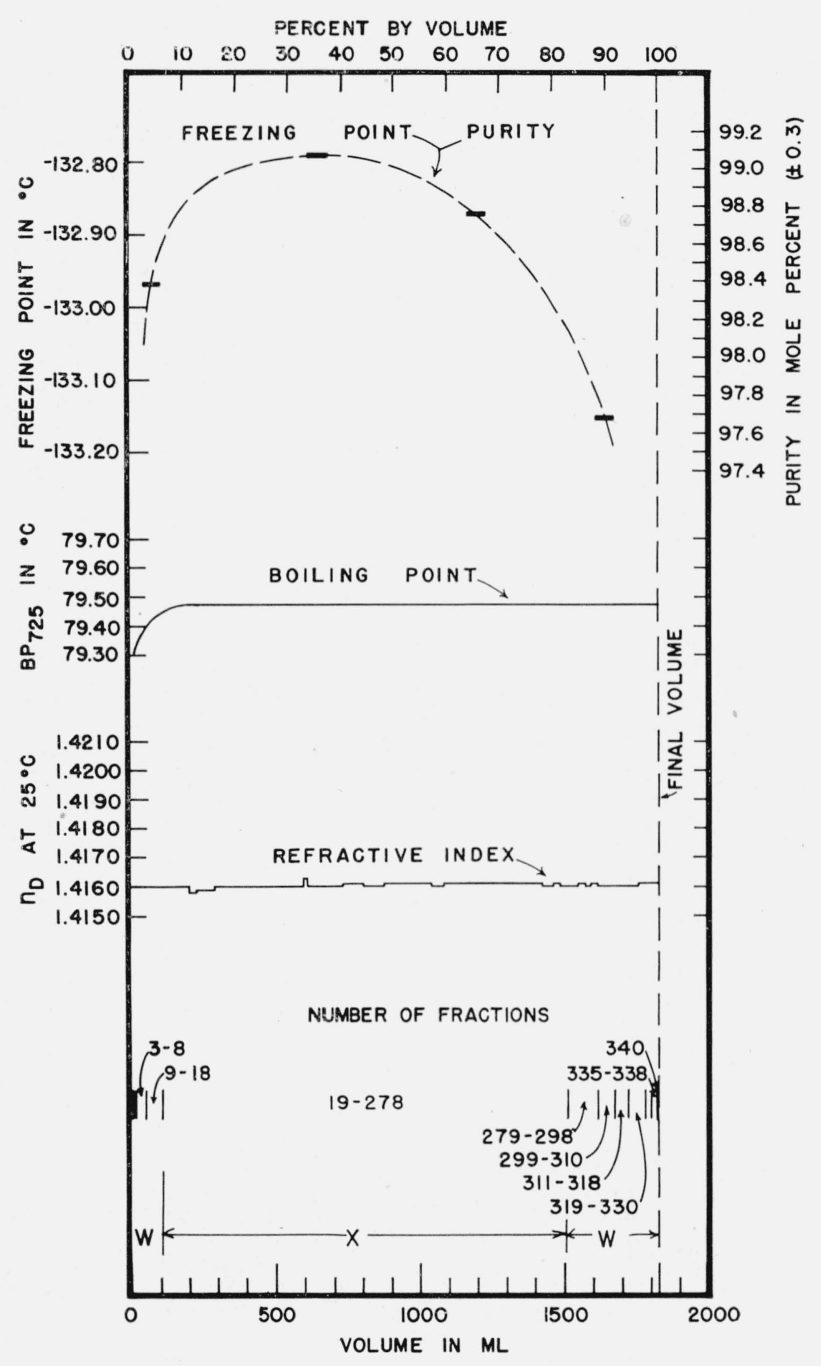

Figure 40.-Results of the second distillation of cis, cis, trans-1,2,4-trimethylcyclopentane.

Azeotropic distillation with isopropanol at $725 \mathrm{~mm} \mathrm{Hg}$ in still $11(6 / 21 / 45$ to $8 / 21 / 45$ ).

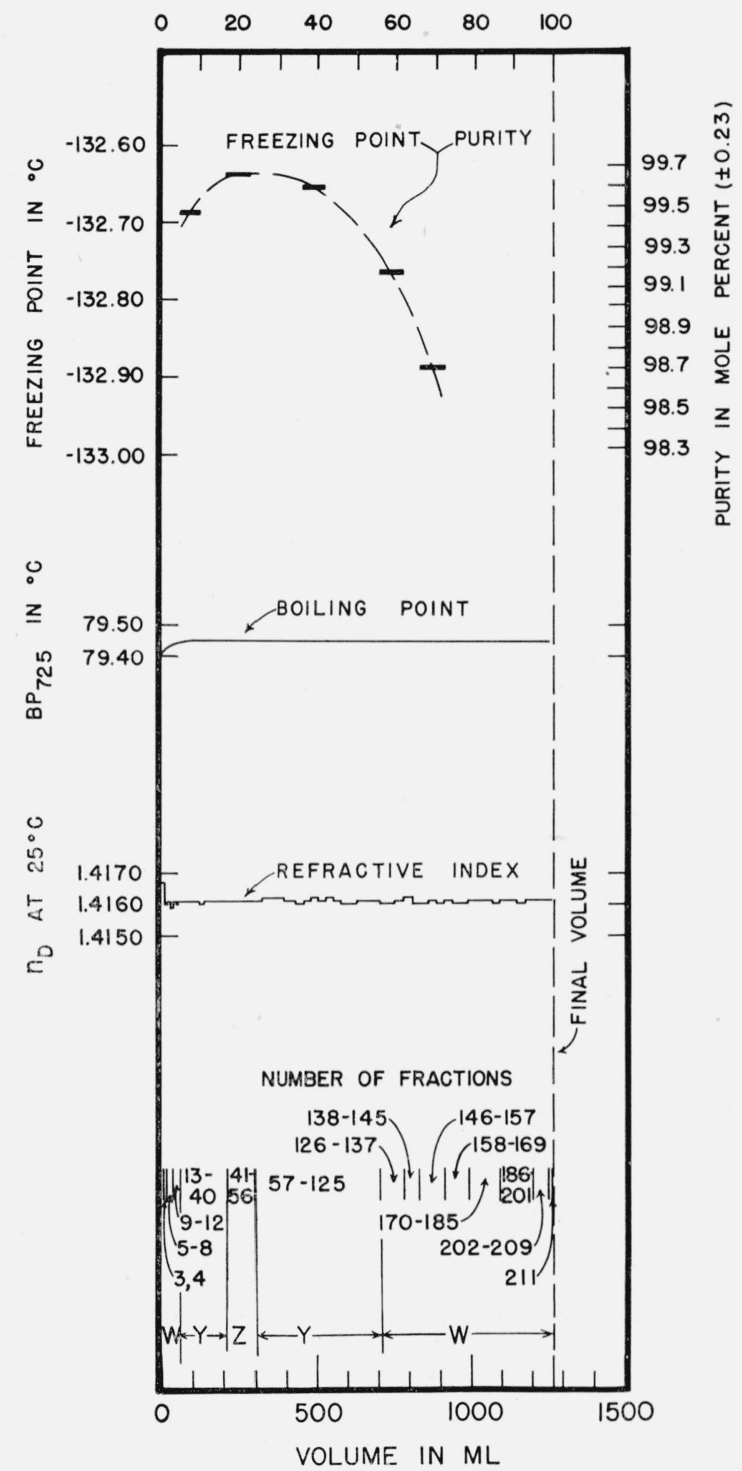

FIgURE 41.-Results of the third and final distillation of cis, cis, trans-1,2,4-trimethylcyclopentane.

Azeotropic distillation with isopropanol at $725 \mathrm{~mm} \mathrm{Hg}$ in still $4(11 / 21 / 45$ to $1 / 3 / 46)$. 


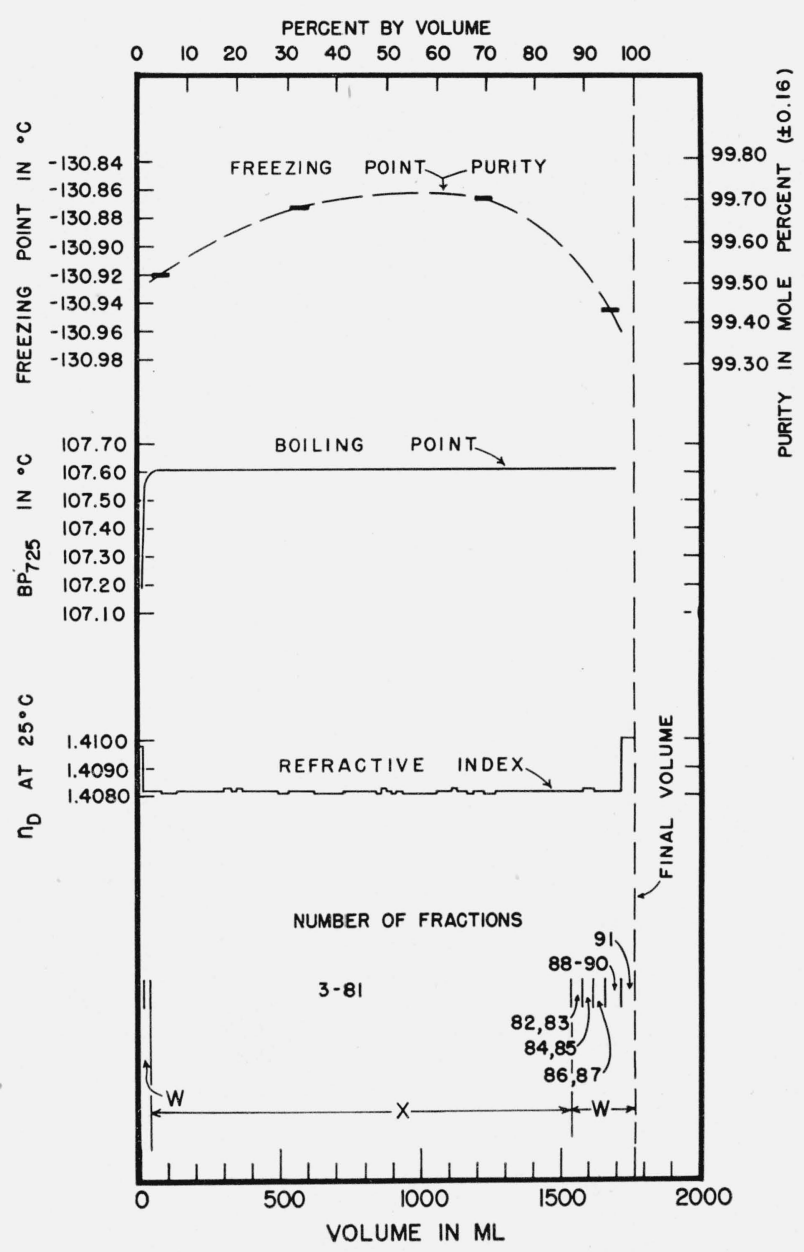

Figure 42.-Results of the first distillation of cis, trans, cis-1,2,4-trimethylcyclopentane.

Regular distillation at $725 \mathrm{~mm} \mathrm{Hg}$ in still 2 (7/19/45 to 9/2/45).

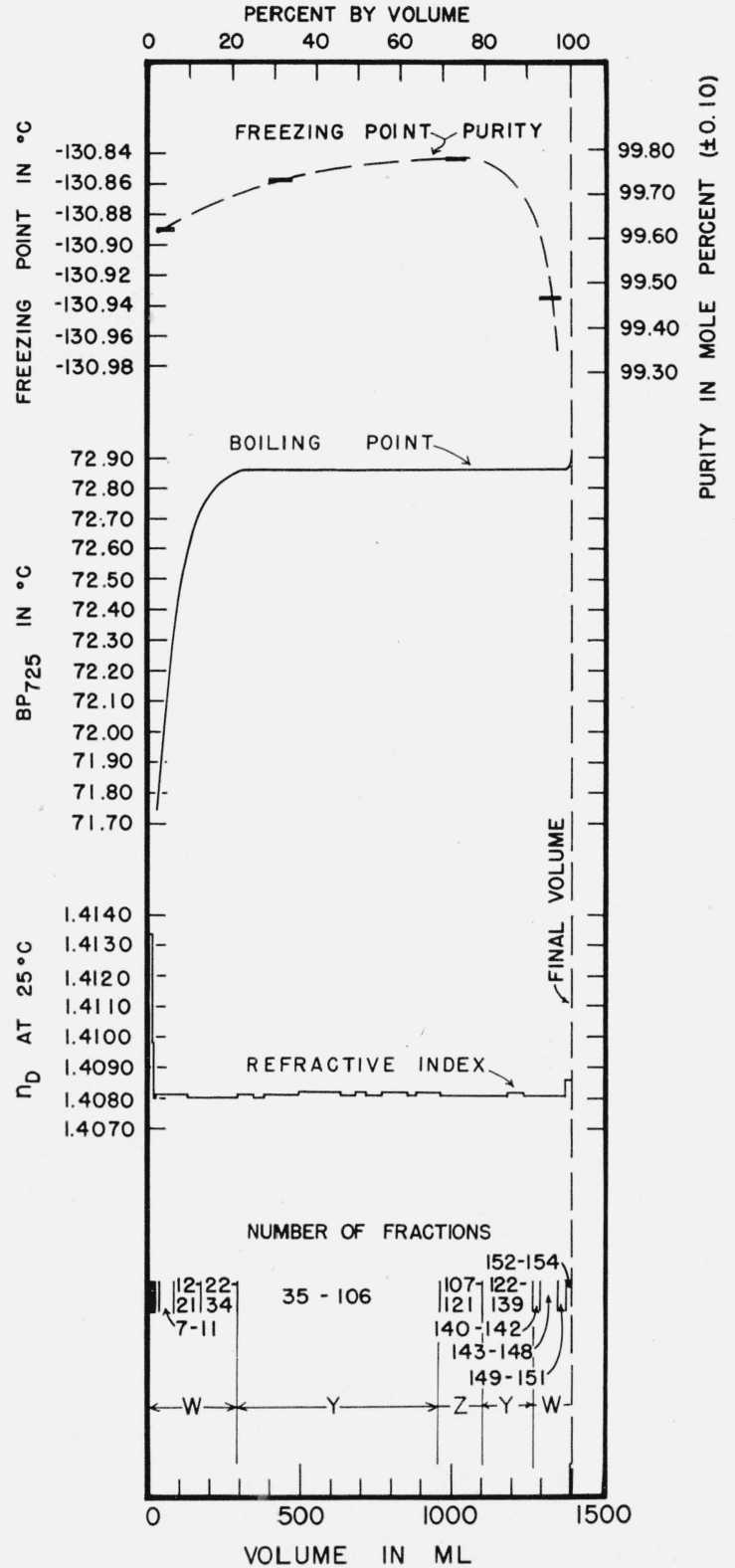

Figure 43.-Results of the second and final distillation of cis, trans, cis-1,2,4-trimethylcyclopentane.

Azeotropic distillation with ethanol at $725 \mathrm{~mm} \mathrm{Hg}$ in still $9(10 / 26 / 45$ to $11 / 23 / 45)$. 


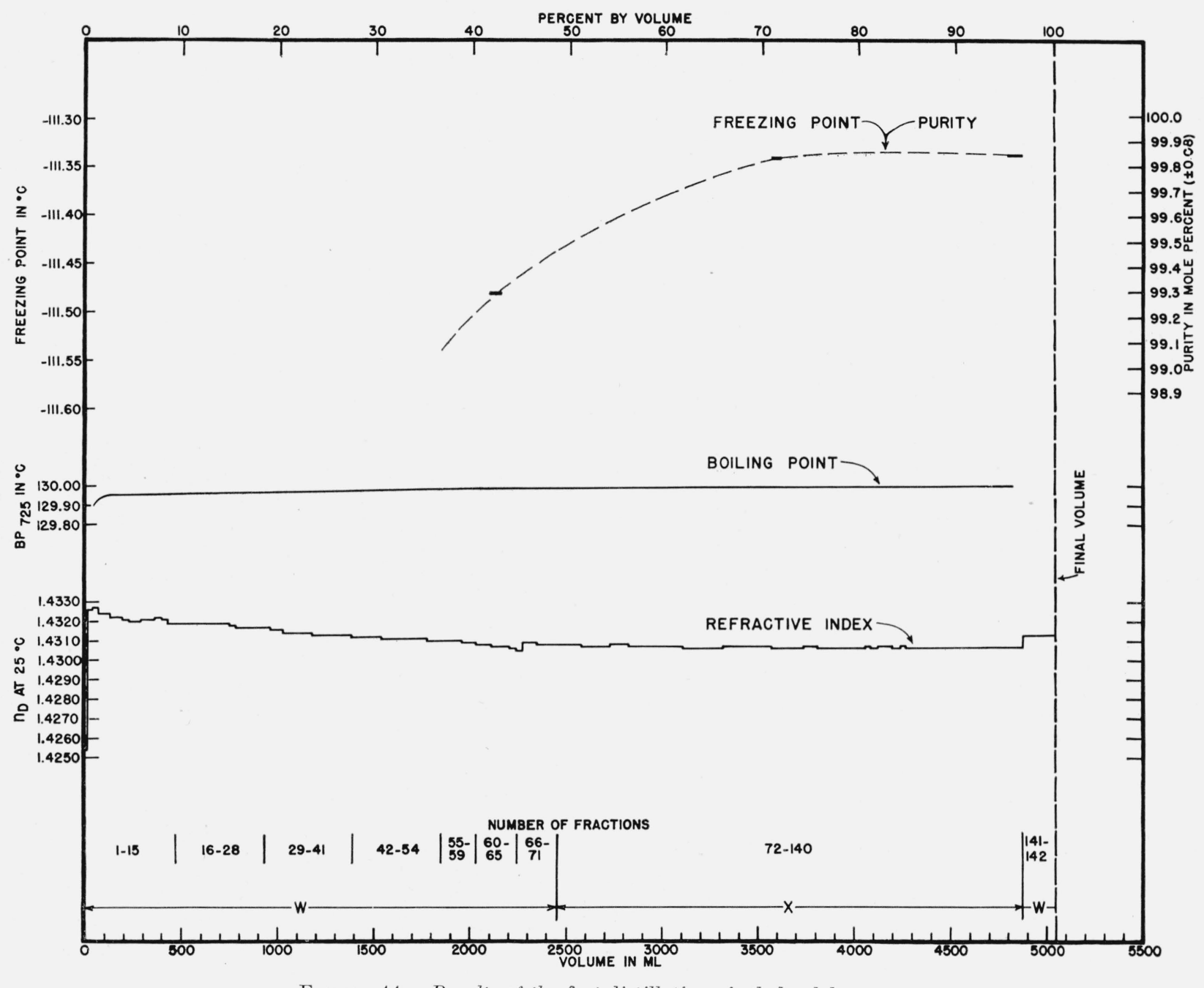

Figure 44.-Results of the first distillation of ethylcyclohexane.

Regular distillation at $725 \mathrm{~mm} \mathrm{Hg}$ in still 8 (7/20/44 to 8/15/44). 


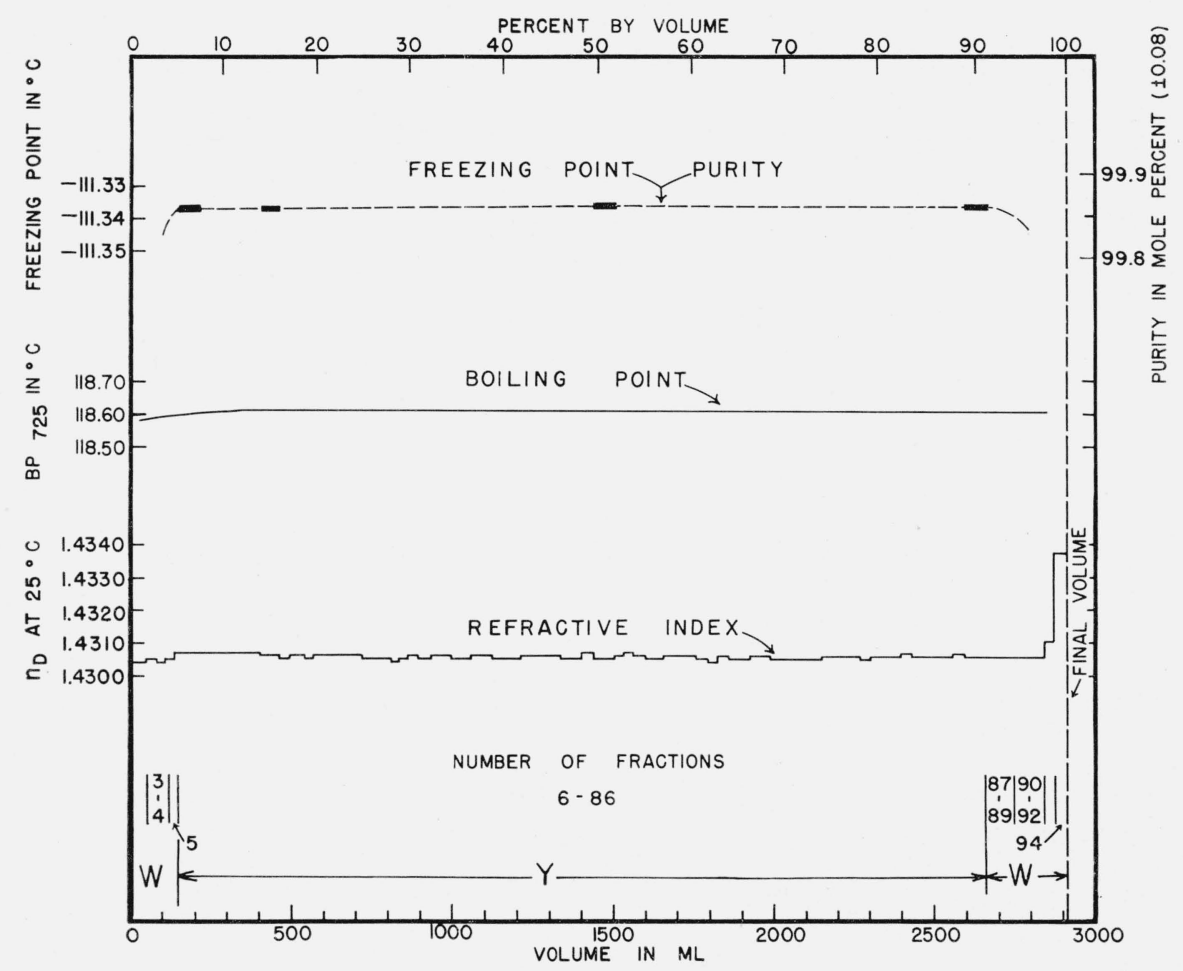

FIGURE 45.-Results of the second and final distillation of ethylcyclohexane.

Azeotropic distillation with ethylene glycol monoethyl ether at $725 \mathrm{~mm} \mathrm{Hg}$ in still 15 (12/16/44 to 1/3/45). See table 1 for composition of the charge for this distillation. 


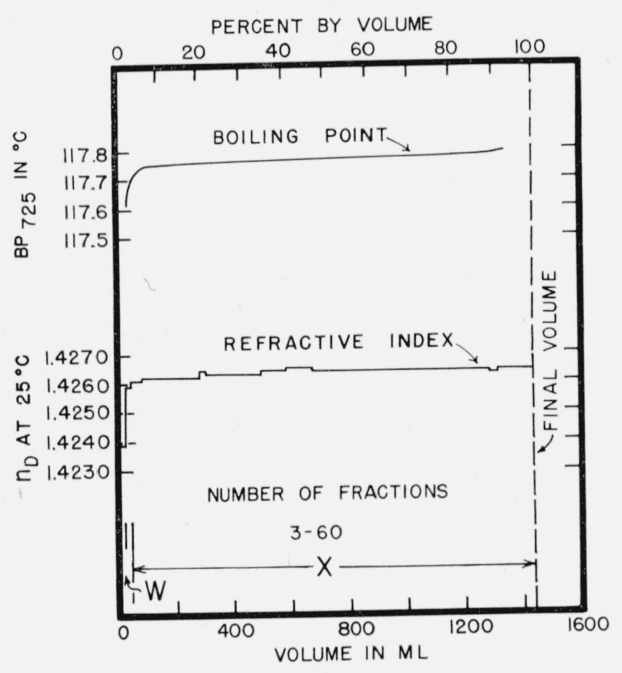

FIGURE 46.-Results of the first distillation of 1,1-dimethylcyclohexane.

Regular distillation at $725 \mathrm{~mm} \mathrm{Hg}$ in still $12(2 / 22 / 45$ to $3 / 11 / 45)$.

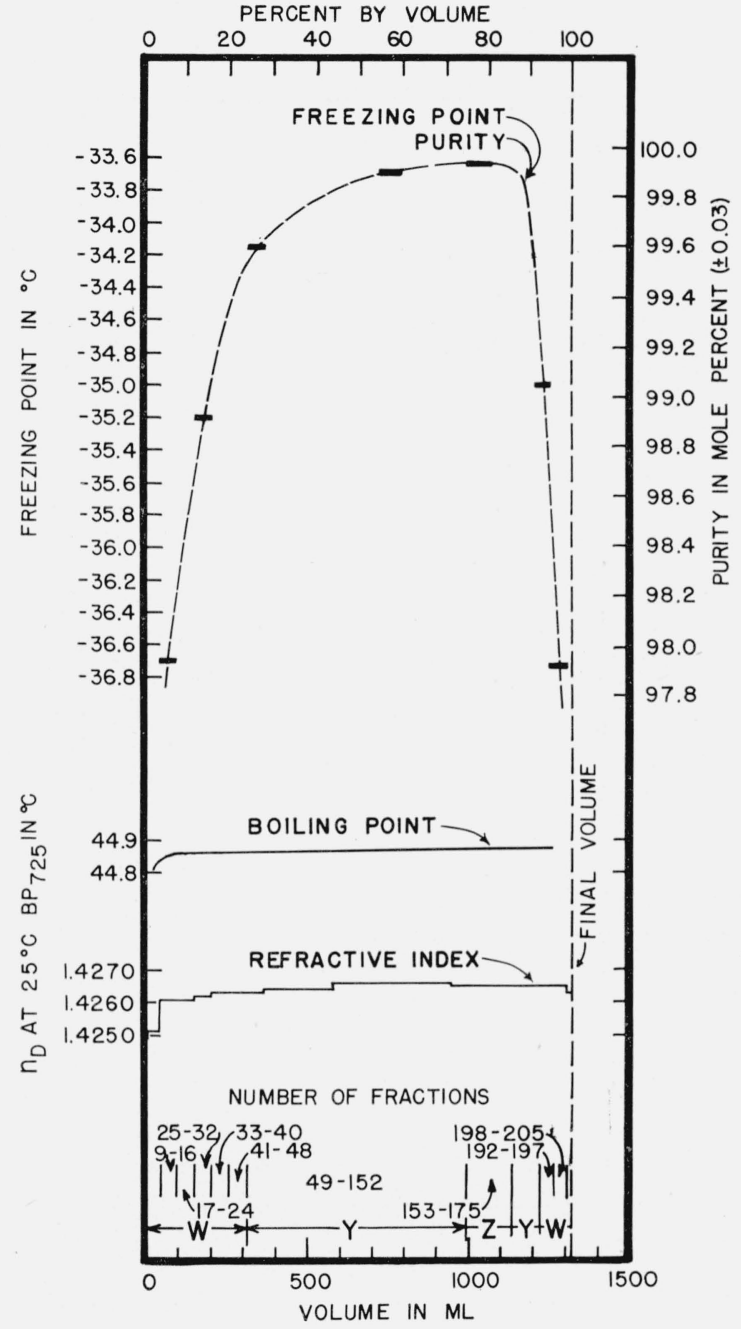

FIGURE 47.-Results of the second and final distillation of 1,1dimethylcyclohexane.

Azeotropic distillation with ethanol at $725 \mathrm{~mm} \mathrm{Hg}$ in still $9(3 / 30 / 45$ to $5 / 7 / 45)$. 


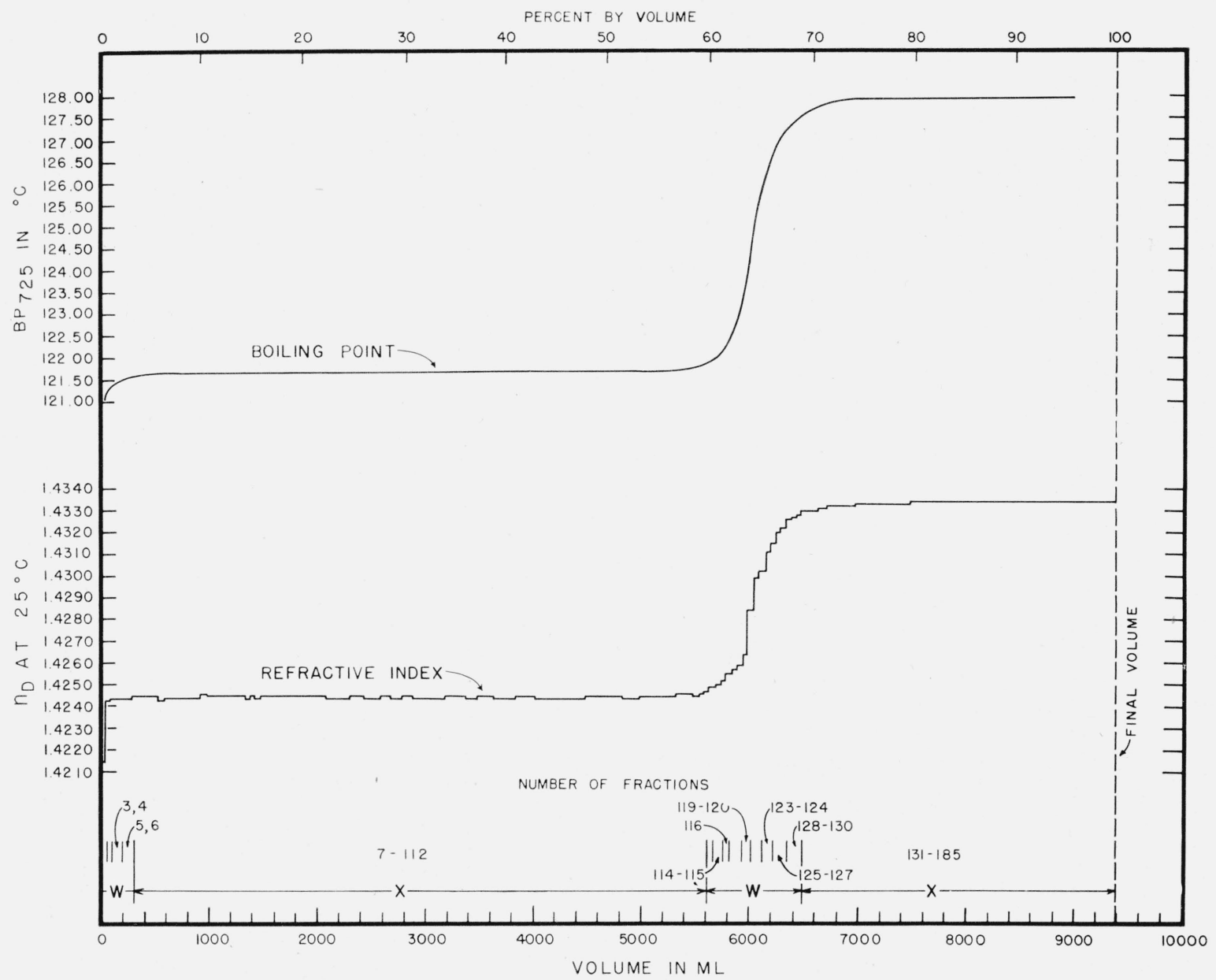

FIGURE 48.-Results of the first distillation of cis- and trans-1,2-dimethylcyclohexane.

Regular distillation at $725 \mathrm{~mm} \mathrm{Hg}$ in still 5 (1/15/45 to 2/16/45).

Fractions 7 to 112 were redistilled to obtain trans-1, 2-dimethylcyclohexane (see fig. 50). Fractions 131 to 185 were redistilled to obtain cis-1,2-dimethyleyclohexane (see fig. 49). 


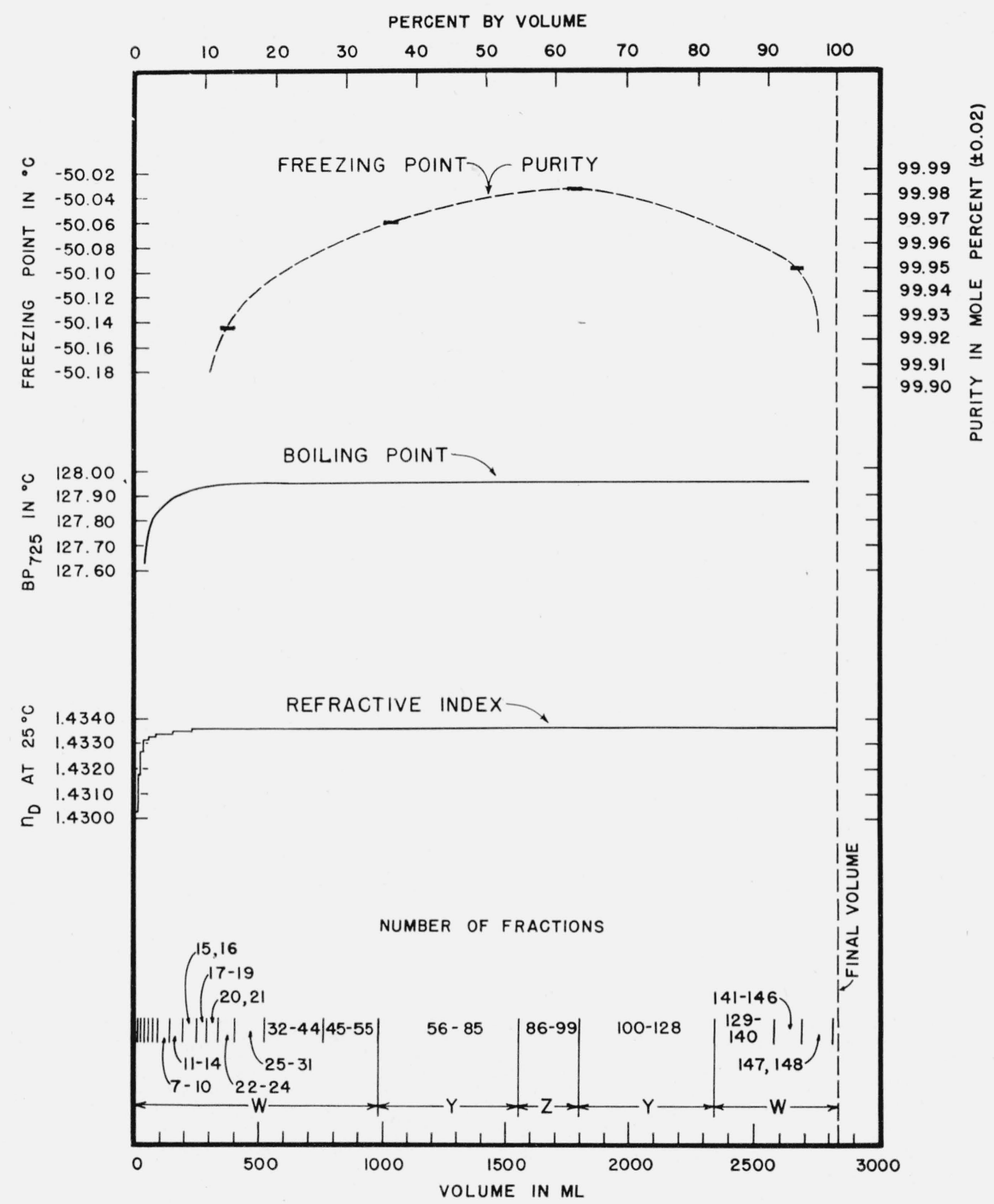

FIGURE 49.-Results of the second and final distillation of cis-1,2-dimethylcyclohexane. Regular distillation at $725 \mathrm{~mm} \mathrm{Hg}$ in still $9(5 / 7 / 45$ to $6 / 4 / 45)$. 


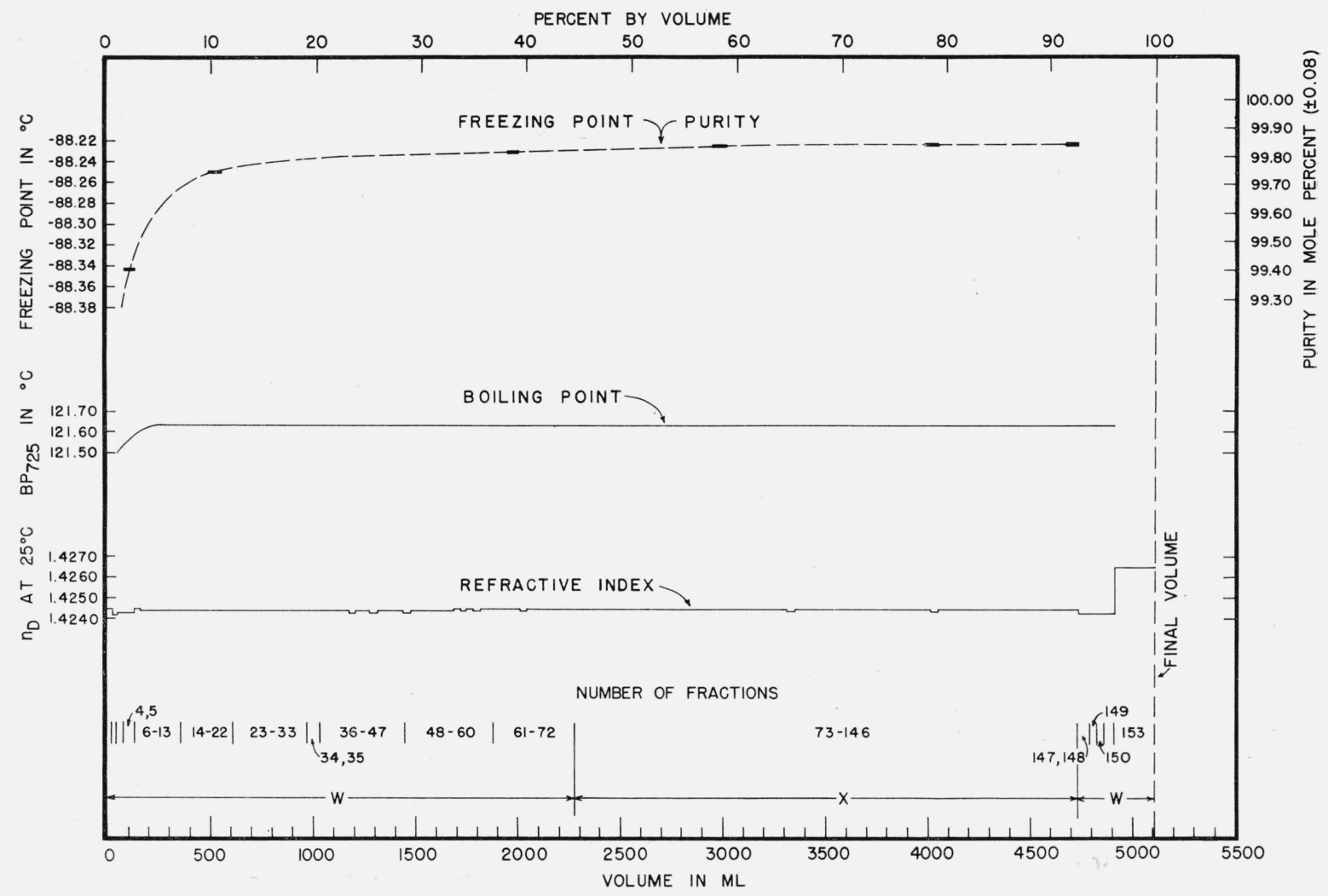

FIGURE 50.-Results of the second distillation of trans-1,2-dimethylcyclohexane. Regular distillation at $725 \mathrm{~mm} \mathrm{Hg}$ in still 7 (3/21/45 to $4 / 23 / 45)$. 


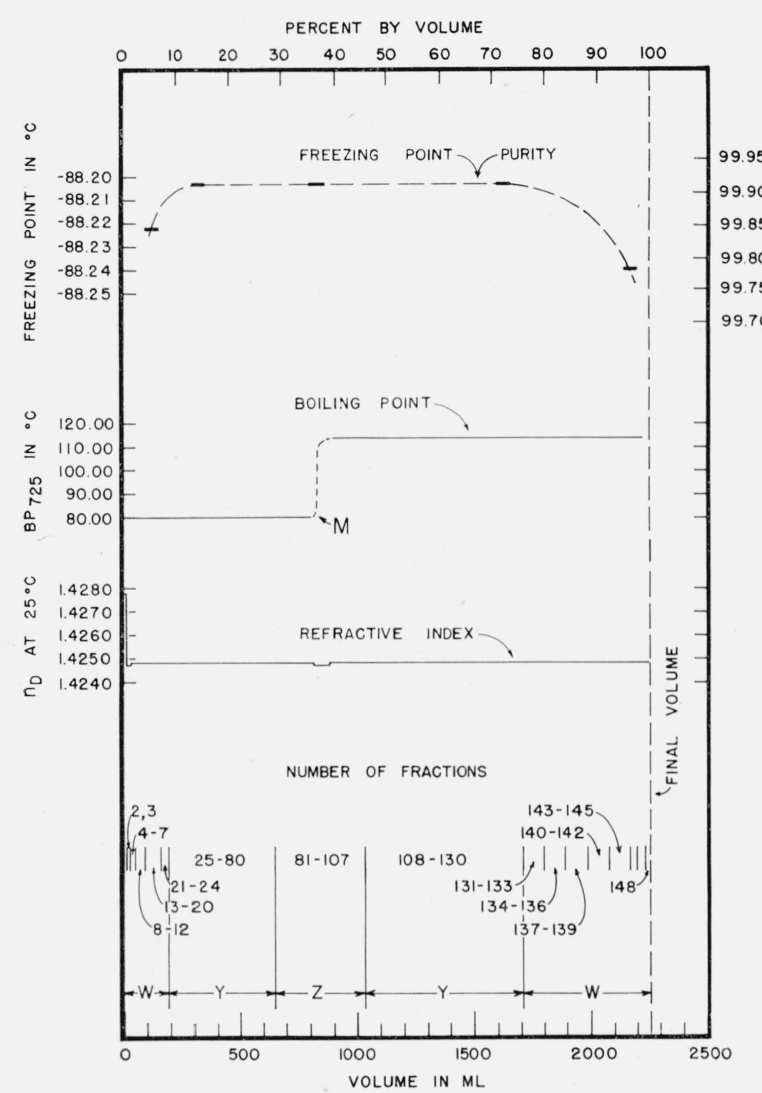

Figure 51.-Results o, the third and final distillation of trans-1,2-dimethylcyclohexane.

Azeotropic distillation with isopropanol and ethylene glycol monoethyl ether at $725 \mathrm{~mm} \mathrm{Hg}$ in still $13(9 / 5 / 45$ to $10 / 11 / 45)$.

The distillate preceding the point marked " $M$ " was distilled with isopropanol as the azeotrope-forming substance, and the remainder of the hydrocarbon was distilled with ethylene glycol monoethyl ether (see footnote $t$ of table 1).

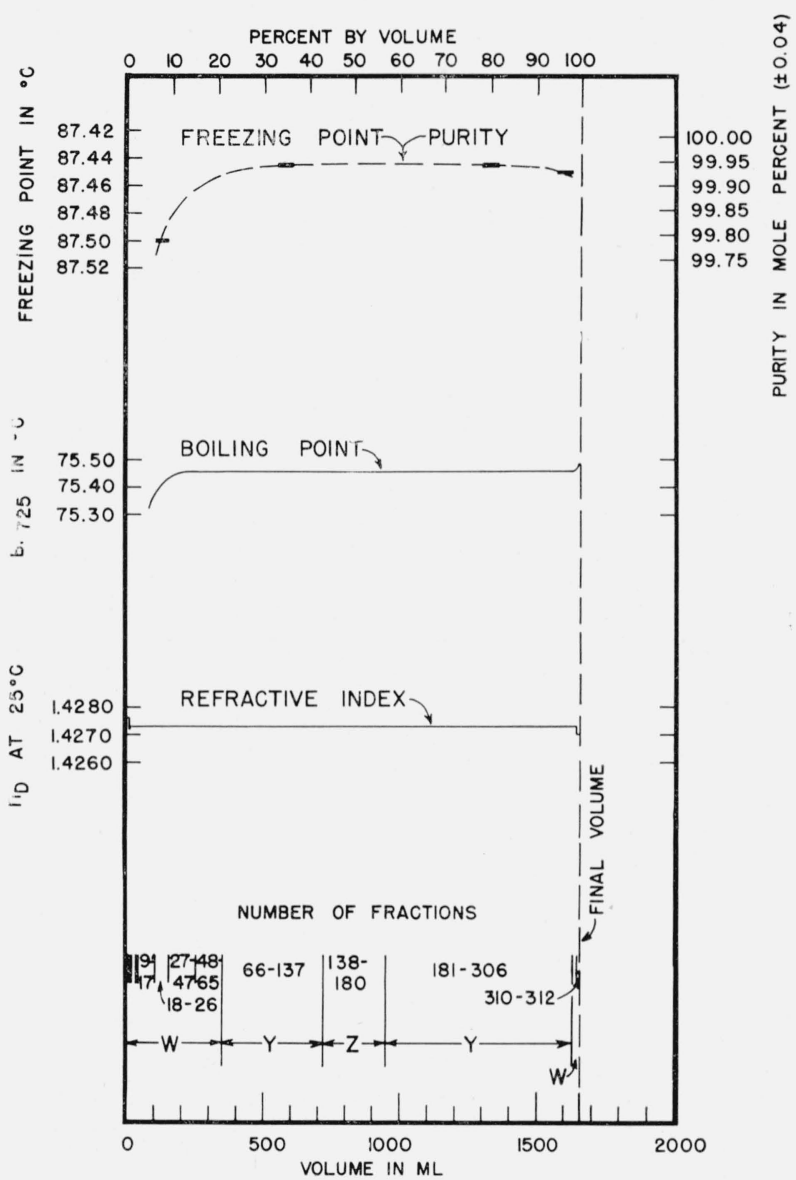

FIGURE 52.-Results of the first and only distillation of cis1,4-dimethylcyclohexane.

Azeotropic distillation with ethanol at $725 \mathrm{~mm} \mathrm{Hg}$ in still 9 (1/8/46 to 3/7/46). 


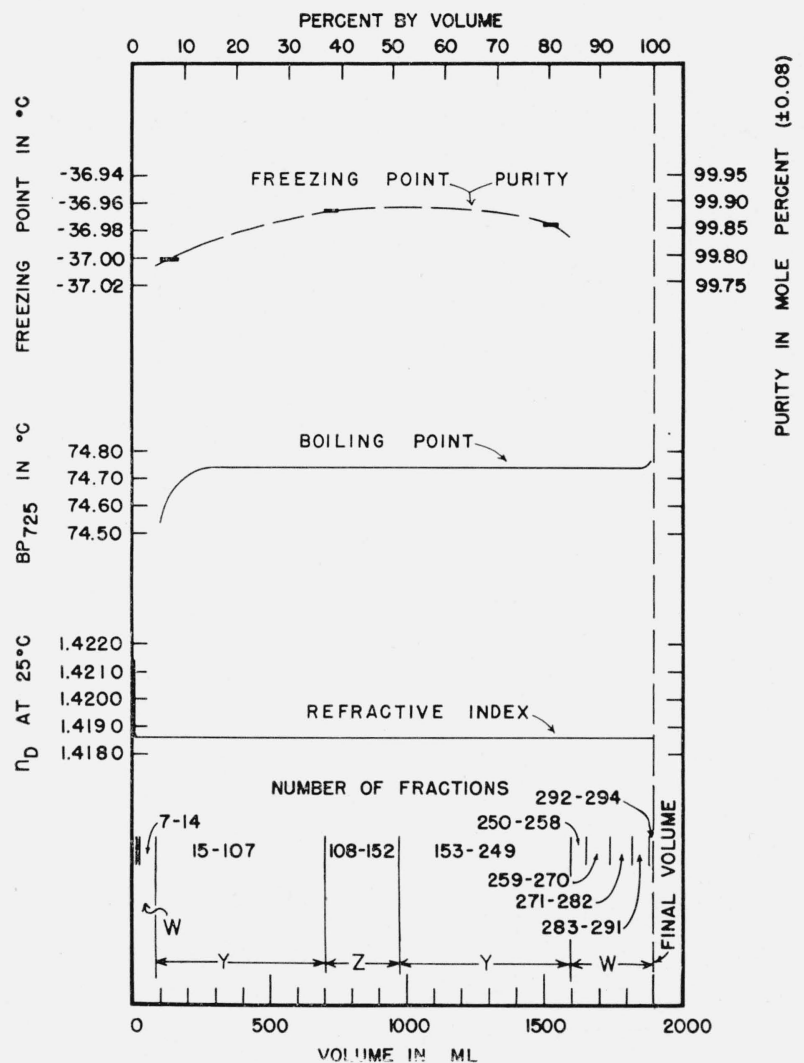

FIGURE 53.-Results of the first and only distillation of trans1,4-dimethylcyclohexane.

Azeotropic distillation with ethanol at $725 \mathrm{~mm} \mathrm{Hg}$ in still $10(1 / 5 / 46$ to $2 / 28 / 46)$.

Washington, June 15, 1946. 